\title{
Effect of Irrigation Water pH on the Performance of Healthy and Huanglongbing-affected Citrus
}

\author{
Lushan Ghimire, Davie Kadyampakeni, and Tripti Vashisth \\ University of Florida/Institute of Food and Agriculture Science, Citrus Research and Education \\ Center, 700 Experiment Station Road, Lake Alfred, FL 33850
}

\begin{abstract}
AdDitional Index words. citrus greening, CLas, plant defense response, RNAseq, soil pH, stress, sweet orange
Abstract. Huanglongbing [HLB (Candidatus Liberibacter asiaticus)] is one of the most devastating diseases in citrus (Citrus sp.). Field observations in Florida have shown that citrus groves with high soil and irrigation water pH decline rapidly under HLB-prevalent conditions. It is worth noting that irrigation water $\mathrm{pH}$ has always been high in Florida; however, neither tree decline nor low productivity under such conditions has been an issue for citrus before HLB. Therefore, there is a need to determine if HLB increases citrus tree sensitivity to high-pH irrigation water. The objective of this research was to evaluate the molecular and physiological responses of healthy and HLB-affected citrus trees irrigated with water at $\mathrm{pH}$ levels of 5.8, 7.0, and 8.0. The results demonstrated that soil pH is positively correlated with irrigation water $\mathrm{pH}$. Overall, regardless of disease occurrence, tree performance decreased as $\mathrm{pH}$ increased. HLB-affected trees at $\mathrm{pH} 8.0$ had the greatest mortality $(40 \%)$ and leaf drop $(87 \%)$ and the lowest height growth $(<1 \%)$ and leaf biomass $(0.1 \mathrm{~g})$. In contrast, HLB-affected trees at pH 5.8 had the lowest mortality $(0 \%)$ and leaf drop (16\%) and the greatest height growth (6.6\%) and leaf biomass (5.5 g). Growth and survival data indicate that high $\mathrm{pH}$ had a less negative impact on healthy trees than HLB-affected trees, and that HLB symptoms were exacerbated at pH 8.0 compared with $\mathrm{pH}$ 5.8. A transcriptomic analysis of root tissue conducted at the end of the experiment further suggested that HLB-affected trees at $\mathrm{pH} 5.8$ were actively detoxing stress-induced radicals and had increased growth and developmental processes with the downregulation of jasmonic acid biosynthesis compared with healthy trees. This implies that at pH 5.8, HLB-affected trees were under less stress than healthy trees. Compared with healthy trees, HLB-affected trees at pH 8.0 resulted in upregulated immune system processes, defense responses, and cell death; no processes were significantly downregulated in HLB-affected trees compared with healthy trees at pH 8.0. Physiological and molecular observations suggest an interaction between HLB and irrigation water pH whereby HLB symptoms are exacerbated in response to high irrigation water $\mathrm{pH}$.
\end{abstract}

Citrus greening, or Huanglongbing (HLB), is one of the most devastating diseases affecting citrus [Citrus sp. (Bove, 2006)]. To date, there is no cure. In Florida, the causal agent of HLB is a phloem-limiting bacteria, Candidatus Liberibacter asiaticus (CLas), which is transmitted by the asian citrus psyllid (Diaphorina citri) (Halbert et al., 2000; Jagoueix et al., 1996). Following infection, a rapid decline in yield can occur even before early foliar symptoms develop (Bassanezi et al., 2011). Significant changes in vital components of the plant system, such as upregulation of stress responses, increased plant defense response, cell death, and imbalance in endogenous hormone levels in leaves and fruit, have been welldocumented during the early and late stages of CLas infection (Martinelli et al., 2012; Nehela et al., 2018).

The roots are the first and most common site of CLas detection and multiplication (Johnson et al., 2014). A significant loss of feeder roots occurs following CLas infection and before visible shoot symptoms develop. Severely damaged roots may limit water and nutrient uptake (Graham et al., 2013; Kadyampakeni et al., 2014), making trees susceptible to other biotic and abiotic stresses. Field trials and observations have shown that feeder root loss in HLB-affected trees is positively

Received for publication 23 Mar. 2020. Accepted for publication 22 July 2020. Published online 19 August 2020.

This work was funded by the Specialty Crop Research Initiative (SCRI) Citrus Disease Research and Extension Program (CDRE; Award \#2017-7001626328).

T.V. is the corresponding author. E-mail: tvashisth@uff.edu.

This is an open access article distributed under the CC BY-NC-ND license (https://creativecommons.org/licenses/by-nc-nd/4.0/). correlated with soil $\mathrm{pH}$ and irrigation water $\mathrm{pH}$ (Morgan and Graham, 2019). These trials demonstrated that HLB-affected trees grown either in high-pH soil or when irrigated with water rich in bicarbonates $\left(>100 \mathrm{mg} \cdot \mathrm{L}^{-1}\right)$ decline rapidly, have excessive fruit drop and loss of yield. The optimum soil $\mathrm{pH}$ range for healthy Florida citrus is 6.0 to 6.5 (Alva et al., 1999); however, most soil in the citrus-growing region of Florida is alkaline, mostly due to the accumulation of bicarbonates (Morgan and Graham, 2019). Similar to soil pH, Florida irrigation water $\mathrm{pH}$ is high $(>7.5)$ due to bicarbonate concentrations greater than $100 \mathrm{mg} \cdot \mathrm{L}^{-1}$ (Graham et al., 2014); therefore, prolonged irrigation with such water further increases the soil $\mathrm{pH}$. The concentrations of carbonate and bicarbonate salts in the soil and irrigation water greatly regulate the $\mathrm{pH}$ and often act as strong buffers (Roosta and Rezaei, 2014). High soil pH limits nutrient availability (especially micronutrients) and can result in osmotic stress or ion toxicity in roots (Golldack et al., 2014; Obreza and Morgan, 2008), triggering the production of reactive oxygen species (ROS) and eventually resulting in cell death (Hanumantharao et al., 2016). To combat and mitigate such stress, plants can increase water uptake and compartmentalize ions (mainly into vacuoles), regulate ion transport and uptake, transfer a phytohormonal signal, and detoxify from ROS (Munns and Gilliham, 2015; Shabala and Mackay, 2011).

The majority of Florida citrus growers currently use strategies to amend soil $\mathrm{pH}$ through various soil acidification methods (Vashisth and Vincent, 2018). Irrigation water in the citrus production region of Florida was high in $\mathrm{pH}$ and bicarbonates before the presence of HLB; however, neither tree decline nor low productivity under such conditions has been an 
issue for citrus before HLB. Currently, no reports have addressed whether high-pH irrigation water exacerbates HLB. Additionally, there is a knowledge gap regarding transcriptomic regulation in HLB-affected citrus roots under high and low $\mathrm{pH}$ conditions. Therefore, we conducted an experiment with healthy (HLY) and HLB trees to gain a better understanding of whether the poor performance of HLB trees under high$\mathrm{pH}$ irrigation water is due to the effects of $\mathrm{pH}$ on nutrient availability or is a physiological response of HLB-affected trees. Although the experiment focused on irrigation water $\mathrm{pH}$, irrigation water $\mathrm{pH}$ can influence soil $\mathrm{pH}$ (Morgan and Graham, 2019); therefore, the implications of this study can be applied to soil $\mathrm{pH}$ as well. The objective of this experiment was to determine the effect of irrigation water $\mathrm{pH}$ on the performance of HLY and HLB-affected citrus. This experiment was performed in a greenhouse because it is not plausible to keep trees HLB-free in open field conditions.

\section{Materials and Methods}

\section{Planting material and growing conditions}

Three-year-old greenhouse-grown 'Midsweet' sweet orange (Citrus sinensis) scion budded on 'Kuharske Carrizo' citrange (C. sinensis $\times$ Poncirus trifoliata) rootstock was used in this study. To obtain HLB-positive trees, CLas-positive buds were grafted on the trees and kept in the greenhouse for HLB symptoms to develop. The healthy trees were grafted with healthy $C$ Las-negative buds and kept in the greenhouse. All trees were confirmed for $C$ Las using quantitative real-time polymerase chain reaction (qPCR) twice as described by Vashisth and Livingston (2019). The first confirmation was performed 3 months after bud inoculation, and the second was performed 1 month before proceeding with the experiment. The experiment was conducted in the greenhouse where trees were grown in $20-\times 10-\mathrm{cm}$ plastic pots containing $\approx 3.6 \mathrm{~kg}$ of sterilized Candler fine sand ( $\mathrm{pH}$ 7.2) collected from an experimental grove at the Citrus Research and Education Center, Lake Alfred, FL. Trees were acclimatized in the sand (growing medium) for 2 weeks before the start of the experiment. Additionally, fertilizer application was halted during the acclimatization period to create nutrient-limited conditions for the trees. On day 0 of the experiment, all trees were fertilized using $12 \mathrm{~N}-$ 5.2P-10K controlled-release fertilizer (Osmocote; ICL Specialty Fertilizers, Summerville, SC) for container-grown citrus trees.

\section{Experimental design}

A complete cross-factorial design with two factors, irrigation water $\mathrm{pH}$ and disease incidence, and eight replicates $(\mathrm{n}=8)$ were used for this study. Three $\mathrm{pH}$ levels were used for irrigation water: 5.8, 7.0, and 8.0. There were two disease incidence levels: HLY and HLB. Sodium phosphate buffers at the three $\mathrm{pH}$ levels were used to irrigate the trees every third day for the duration of the study; care was taken to minimize leaching during irrigation. The buffers were prepared according to Mohan (2003), and a pH meter (Thermo Fisher Scientific, Waltham, MA) was used to verify the $\mathrm{pH}$ values. Hereafter, treatment combinations are referred to in the form of " $\mathrm{pH}$ level-disease level" (e.g., HLB-affected trees treated with $\mathrm{pH}$ 5.8 are expressed as $\mathrm{pH}$ 5.8-HLB). The planned experiment duration was 4 months; however, due to the tree response to high-pH irrigation water (discussed in the Results), the study was ended after 2 months $(60 \mathrm{~d})$.
SoIL PROPERTIES. For each tree, $\mathrm{pH}$ and electrical conductivity (EC) were measured in a $10-\mathrm{g}$ soil subsample collected using a $10-\mathrm{cm}$ core on days 0,30 , and 60 . The $\mathrm{pH}$ was measured using a $\mathrm{pH}$ meter according to the protocol described by Mylavarapu et al. (2020). Soil EC was measured using a soil moisture meter (TDR 150, model 6435; Spectrum Technologies, Aurora, IL) according to the manufacturer's protocol.

Tree Growth. Tree height, trunk diameter, and number of leaves were measured on days 0,30 , and 60 to monitor growth over time. A well-calibrated Vernier caliper was used to measure the tree diameter just above the graft union. Tree height was measured using a metric ruler. The graft union was considered the base for measuring tree height. Tree height and trunk diameter are presented as the percent change in height or diameter by calculating the difference in the measurements from the start to the end of the experiment. The number of leaves were counted manually. The soil plant analysis development (SPAD) value estimated the total leaf chlorophyll content of five fully expanded, randomly selected, mature leaves per tree using a chlorophyll meter (MC-100 Chlorophyll Concentration Meter; Apogee Instruments, Logan, UT). The five SPAD values of each tree were averaged for a representation of the chlorophyll content on days 0 and 60 . Tree biomass was determined for the leaf, stem, and root separately at the end of the experiment (day 60). The fresh weight of each leaf, stem, and root tissue was recorded immediately following the completion of the experiment. For dry weight, tissues were ovendried at $65{ }^{\circ} \mathrm{C}$; leaves were dried for $3 \mathrm{~d}$ and stems and roots were dried for $5 \mathrm{~d}$ and measured.

Mineral nutrient analysis. Soil and leaf tissues were sampled on day 60 to determine mineral nutrient concentrations in response to the treatment. Leaves were washed with a $1 \%$ acidic soap solution, oven-dried at $65^{\circ} \mathrm{C}$ for $72 \mathrm{~h}$, and finely ground using an analytical mill (Fex IKA A11; IKA-Werke, Staufen, Germany). Ground leaf (20 g) and soil samples (200 g) were sent to Waters Agricultural Laboratories (Camilla, GA) for standard nutrient analyses. Soil nutrient $(\mathrm{P}, \mathrm{Ca}, \mathrm{Mg}, \mathrm{K}, \mathrm{Zn}$, $\mathrm{Mn}, \mathrm{Fe}, \mathrm{B}, \mathrm{Cu})$ concentrations were determined using the Mehlich I test method (Mehlich, 1953).

Rna EXTRACTION. Feeder roots, $\approx 2 \mathrm{~cm}$ long from the root tips, were sampled from every replicate per treatment on day 60 . Immediately after collection, roots were washed, flashfrozen in liquid nitrogen, and stored at $-80{ }^{\circ} \mathrm{C}$ until further analysis. Total RNA was isolated from $100 \mathrm{mg}$ of sampled roots using the RNeasy Mini Plant RNA Extraction kit (Qiagen, Valencia, CA). A spectrophotometer (Epoch 2 Microplate; Biotek Instruments, Winooski, VT) and denaturing formaldehyde $1.2 \%$ agarose gels (Rio, 2015) were used to assess the quantity and quality of RNA, respectively.

TransCriptomic analysis. To determine and compare the effects of extreme treatments at the transcriptomic level, $\mathrm{pH}$ 5.8-treated and $\mathrm{pH}$ 8.0-treated HLY and HLB roots were selected. Total RNA from four treatments $(n=4$; each of two replicates was pooled to one) were sent to the BGI Group (Shenzen, China) for RNA sequencing (RNA-seq, BGISEQ500). BGISEQ-500 library construction and BGISEQ-500 platform (BGI Group) were performed for transcript sequencing as described by Zhu et al. (2018). The sequenced reads were then sent to the Interdisciplinary Center for Biotechnology Research, University of Florida (Gainesville) for sequence alignment and differential gene expression (DEG) analysis. The sequenced transcripts were annotated using Citrus sinensis 
v1.0 genome from the Phytozome database (Wu et al., 2014). To identify the significant DEG in the contrasts (HLY vs. HLB) at $\mathrm{pH} 5.8$ and 8.0 , the absolute value of the $\log _{2}$ fold change greater than 1 and the false discovery rate (FDR)-corrected $P<$ 0.1 were used as thresholds.

GENE ONTOLOGY ENRICHMENT ANALYSIS. To investigate the biological significance of the results of RNA-seq, DEG from the $\mathrm{pH} 5.8$ and 8.0 treatments were subjected to Gene Ontology (GO) enrichment analysis using AgriGO with Fisher's exact test (Tian et al., 2017). Redundant GO terms were further removed using REViGO (Supek et al., 2011).

Gene EXPRESSion ANALYsis. A subset of six genes from the RNA-seq analysis was selected for the expression analysis to validate the results. Gene-specific primers were designed using Primer BLAST (National Center for Biotechnology Information, 2018). The details of genes and primer sequences are provided in Supplemental Table 1.

For cDNA synthesis, $1 \mu \mathrm{g}$ of total RNA was treated with DNase I (RQ1; Promega, Madison, WI) and used in the firststrand cDNA synthesis using oligo $(\mathrm{dT})_{15}$ primer, dNTP mix, and reverse transcriptase (ImProm-II; Promega) in a $20-\mu \mathrm{L}$ reaction using thermo cycler (C1000 Touch Thermal Cycler; Bio-Rad Laboratories, Hercules, CA).

A $10-\mu \mathrm{L}$ total volume qPCR reaction system with $20 \mathrm{ng}$ of RNA, $300 \mathrm{nM}$ of forward and reverse primers, and SYBR green reagent mix (Applied Biosystems PowerUp SYBR Green Master Mix 2X; Thermo Fisher Scientific) was performed using a real-time PCR system (Applied Biosystems 7500 Fast Real-Time PCR System; Thermo Fisher Scientific). Each reaction was performed at $50{ }^{\circ} \mathrm{C}$ for $2 \mathrm{~min}$ and $95{ }^{\circ} \mathrm{C}$ for 2 min, followed by 40 cycles of $95^{\circ} \mathrm{C}$ for $3 \mathrm{~s}$ and $60{ }^{\circ} \mathrm{C}$ for $30 \mathrm{~s}$. At the end of each $\mathrm{qPCR}$ run, dissociation curve analyses ranging from 60 to $95{ }^{\circ} \mathrm{C}$ were performed to confirm the formation of specific products. The Pfaffl method was adopted to calculate the levels of the relative expression $\left(\log _{2}\right.$ fold change) of genes using the quantification cycle $(\mathrm{Ct})$ (Hellemans et al., 2007; Pfaffl, 2001). Glyceraldehyde-3-phosphate dehydrogenase $\mathrm{C} 2$ (GAPC2) and the gene for DIM1 homologue/YLS8 were used as the normalization genes (Mafra et al., 2012).

\section{Statistical analysis}

A two-way analysis of variance (ANOVA) was used to determine the effects of different irrigation water $\mathrm{pH}$ levels (5.8, 7.0, and 8.0), disease incidences (HLY and HLB), and their interaction with tree growth and development, leaf SPAD value, soil $\mathrm{pH}$, soil EC, and mineral nutrient concentrations of soil and leaves using a general linear model in R-studio ( $\mathrm{R}$ version 3.4.1; R-core team, Vienna, Austria). Tukey's honestly significant difference test was used to perform post hoc comparisons at $\alpha \leq 0.05$ when the ANOVA test indicated significant differences. Pearson's correlation analysis was performed using R-studio ( $\mathrm{R}$ version 3.4.1; R-core team) for tree growth parameters and irrigation water $\mathrm{pH}$ for HLB and HLY trees, respectively, by including all the data points in each set $(n=24)$.

\section{Results}

The experiment was planned to continue for 4 months; however, due to a rapid decline in the $\mathrm{pH} 8.0$-treated trees, the experiment was concluded at 2 months $(60 \mathrm{~d})$.

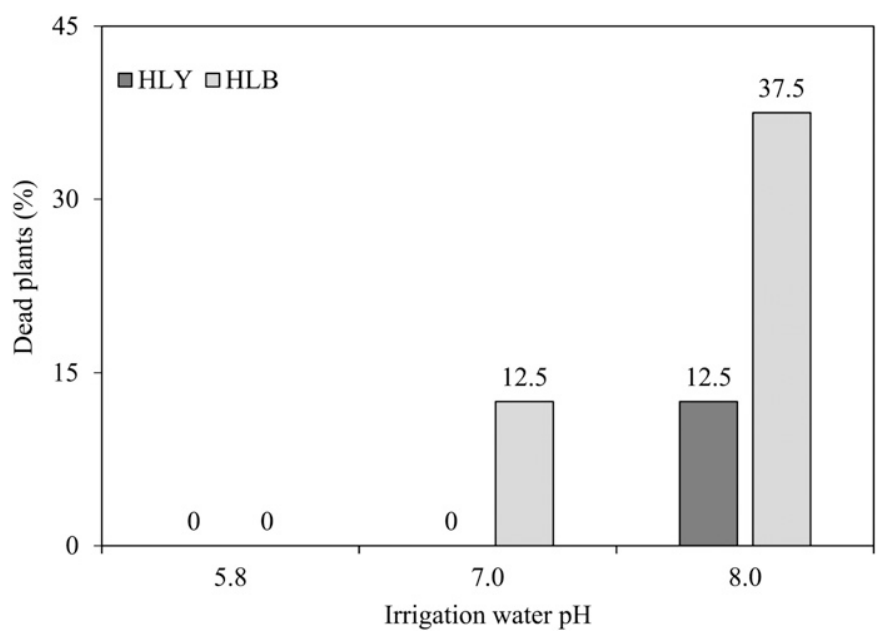

Fig. 1. Percentage of dead healthy (HLY) and Huanglongbing-affected (HLB) sweet orange trees after $60 \mathrm{~d}$ of treatment with irrigation water at $\mathrm{pH}$ levels of $5.8,7.0$, or $8.0(\mathrm{n}=8)$.

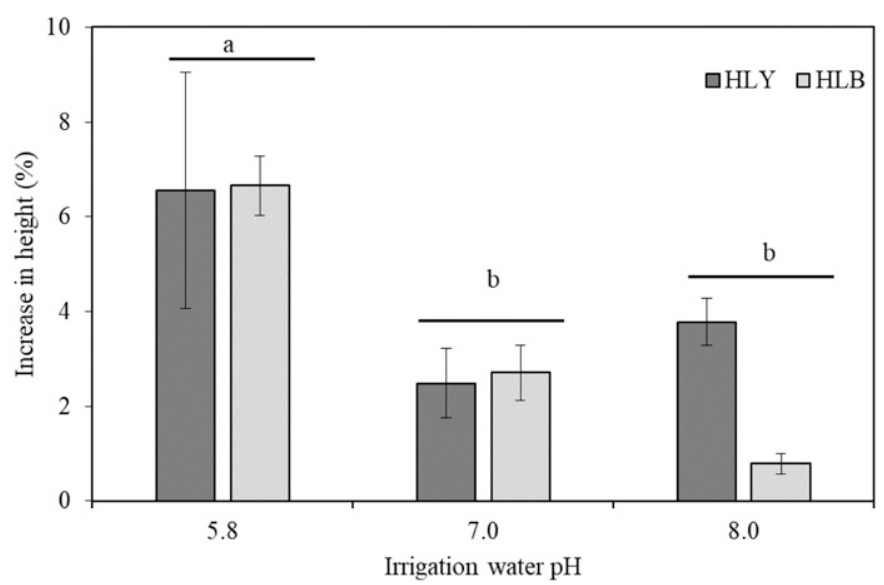

Fig. 2. Increase in height (mean $\pm \mathrm{SE}$ ) of healthy (HLY) and Huanglongbingaffected (HLB) sweet orange trees treated with irrigation water at $\mathrm{pH}$ levels of $5.8,7.0$, or 8.0 for $60 \mathrm{~d}(\mathrm{n}=8)$. The increase in plant height was calculated as the difference in plant height at the start and end of the experiment. Different letters indicate significant differences in the increase in height of plants treated with different $\mathrm{pH}$ regardless of the disease incidence using Tukey's honestly significant difference test at $P<0.05$.

SoIL PROPERTIEs. The irrigation water $\mathrm{pH}$ treatment positively affected the $\mathrm{pH}$ of the soil (Supplemental Fig. 1). However, the soil $\mathrm{pH}$ was not the same as the irrigation water $\mathrm{pH}$ after $60 \mathrm{~d}$ of treatment. On day 60, with the $\mathrm{pH} 5.8$ treatment, the soil $\mathrm{pH}$ was higher than 5.8; with the $\mathrm{pH} 7.0$ treatment, the soil $\mathrm{pH}$ was close to 7.0 ; and with the $\mathrm{pH} 8.0$ treatment, the soil $\mathrm{pH}$ was lower than 8.0. This indicates that Candler Fine sand has $\mathrm{pH}$-buffering capacity.

The EC of the soil increased with increases in irrigation water $\mathrm{pH}(P<0.001)$ and HLB $(P<0.001)$ (Supplemental Fig. $2)$, although there was no significant interaction $(\mathrm{pH} \times$ disease $)$ at any time point. The soil EC of the HLY trees was significantly lower $\left(1.02 \mathrm{mS} \cdot \mathrm{cm}^{-1}\right)$ than the soil EC of HLB-affected trees $\left(1.38 \mathrm{mS} \cdot \mathrm{cm}^{-1}\right)$. The soil of $\mathrm{pH}$ 8.0-HLB trees had the highest EC $\left(1.3 \mathrm{mS} \cdot \mathrm{cm}^{-1}\right)$. The soil of $\mathrm{pH} 5.8-\mathrm{HLY}$ trees had the lowest EC value $\left(0.6 \mathrm{mS} \cdot \mathrm{cm}^{-1}\right)$. 


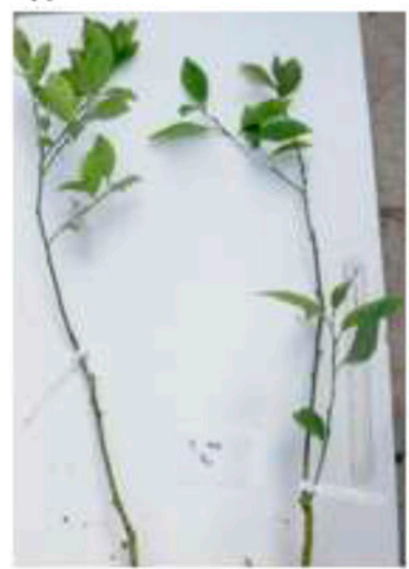

D
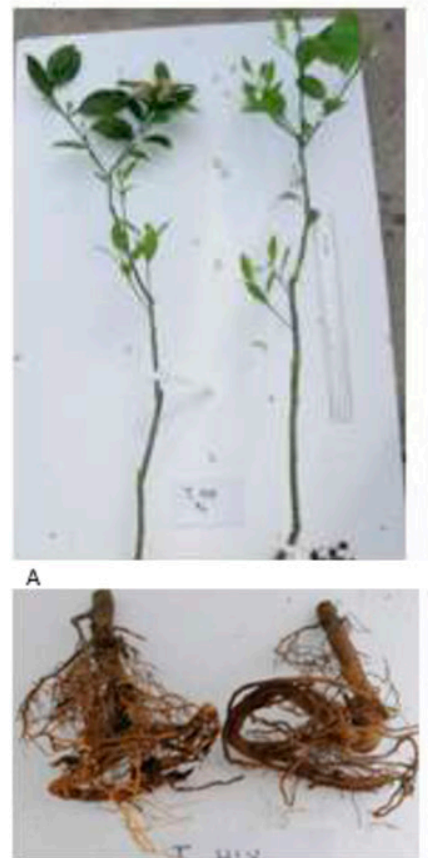

D

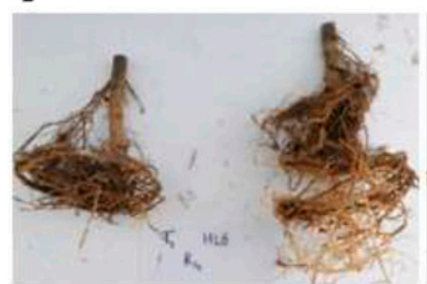

B

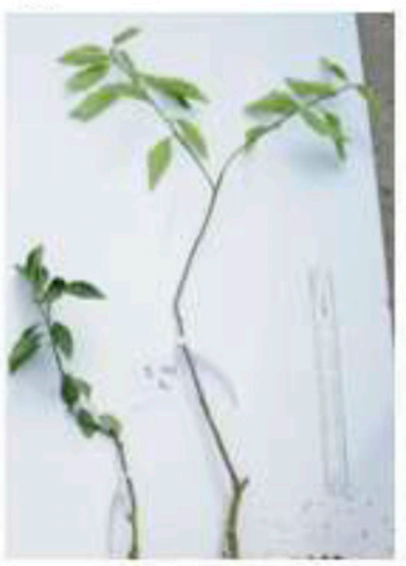

E

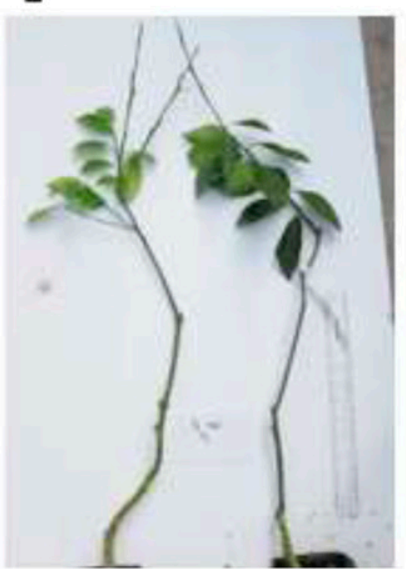

B

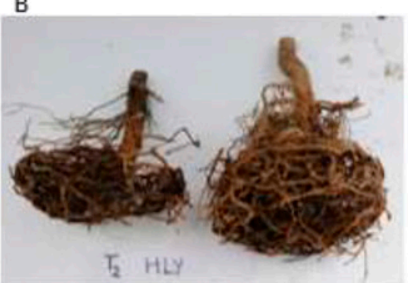

$\mathrm{E}$

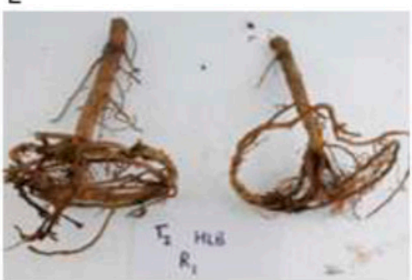

Fig. 3. Images of the shoot system (top) and root system (bottom) of (A) healthy (HLY) sweet orange trees treated with irrigation water at $\mathrm{pH} 5.8$, (B) HLY sweet orange trees treated with irrigation water at $\mathrm{pH} 7.0$, (C) HLY sweet orange trees treated with irrigation water at $\mathrm{pH}$ 8.0, (D) Huanglongbing (HLB)-affected sweet orange trees treated with irrigation water at $\mathrm{pH} 5.8,(\mathbf{E}) \mathrm{HLB}$-affected sweet orange trees treated with irrigation water at $\mathrm{pH}$ 7.0, and (F) HLB-affected sweet orange trees treated with irrigation water at $\mathrm{pH} 8.0$ for a duration of $60 \mathrm{~d}$. A 30$\mathrm{cm}$ ruler is shown in the background of the shoot system.

Tree Growth and survival. After $60 \mathrm{~d}$, trees subjected to the $\mathrm{pH}$ 8.0-HLB treatment had the highest mortality (37.5\%) compared with the $\mathrm{pH} 8.0-\mathrm{HLY}$ trees (12.5\% mortality), and no mortality occurred for $\mathrm{pH} 5.8-\mathrm{HLY}$ or $\mathrm{pH} 5.8-\mathrm{HLB}$ trees (Fig. 1). Only pH had a significant effect on tree height $(P<0.001)$

C

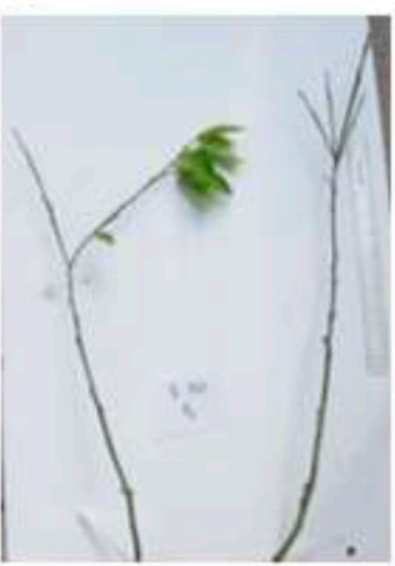

$\mathrm{F}$

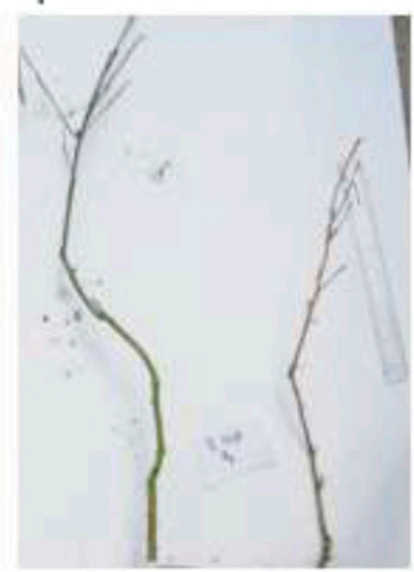

c

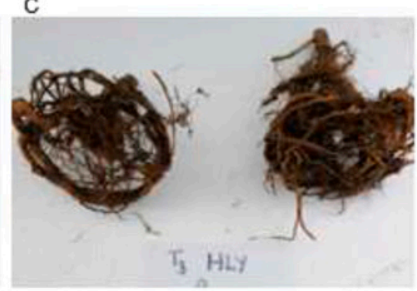

$\mathrm{F}$

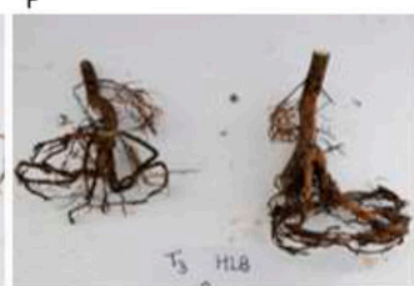

(Fig. 2). The HLB trees at $\mathrm{pH} 5.8$ showed a $6.6 \%$ increase in height, whereas at $\mathrm{pH} 8.0$ the increase was $0.78 \%$. For HLY trees, there was a $6.5 \%$ increase in height at $\mathrm{pH} 5.8$; however, at $\mathrm{pH} 8.0$, the increase was $\approx 3.8 \%$. For HLB trees, the increase in height was negatively correlated with the increase in $\mathrm{pH}(\mathrm{r}=-0.85$; $P<0.05)$. Interestingly, there was no significant correlation between the increase in height and $\mathrm{pH}$ treatment among the HLY trees. Trunk diameter did not show a significant difference in any of the treatments; however, a significant negative correlation was observed between trunk diameter and $\mathrm{pH}$ treatment among HLB trees $(\mathrm{r}=-0.72 ; P<$ $0.05)$. No significant correlation was recorded for HLY trees. At day 0, all trees had approximately the same number of leaves. After $60 \mathrm{~d}$, there was an overall decrease in the number of leaves with an increase in $\mathrm{pH}$ $(P<0.001)$ (Supplemental Fig. 3), and no effect of disease was observed. Furthermore, $\mathrm{pH} 8.0$ resulted in the greatest leaf drop: $75 \%$ in HLY trees and $87 \%$ in HLB trees. In contrast, pH 5.8 resulted in leaf drop of $29 \%$ for HLY and $18 \%$ for HLB trees. A significant positive correlation between irrigation water $\mathrm{pH}$ and leaf drop was observed for HLY $(\mathrm{r}=0.57 ; P<0.05)$ and HLB trees $(\mathrm{r}=0.75 ; P<0.05)$, respectively. The positive correlation was also evident upon observation of the shoot system of the tree (Fig. 3). There was no effect of disease or interaction $(\mathrm{pH} \times$ disease) on leaf biomass, although the $\mathrm{pH}$ treatment did have a significant effect $(P<$ 0.001) (Fig. 4). In general, the leaf biomass gradually decreased with an increase in irrigation water $\mathrm{pH}$. A negative correlation between leaf dry weight and $\mathrm{pH}$ treatment was observed for both HLY $(\mathrm{r}=-0.84$; $P<0.05)$ and HLB trees $(\mathrm{r}=-0.91$; $P<0.05)$. No significant differences were observed for root fresh weight. Nevertheless, there was a significant effect of disease on root dry weight $(P=0.001)$ (Supplemental Fig. 4); HLB-affected trees had lower root dry weight than HLY trees, irrespective of the $\mathrm{pH}$ treatment. Upon visual inspection, significant root loss and root dieback were observed for $\mathrm{pH}$ 8.0-HLB and $\mathrm{pH} 7.0-\mathrm{HLB}$ trees, whereas the growth of new feeder roots was apparent in pH 5.8-HLB trees (Fig. 3). 
The SPAD value on day 0 of the experiment was similar for all trees, but no significant effect of disease or interaction $(\mathrm{pH} \times$ disease) was observed by day 60 . There was a significant difference in the chlorophyll content in response to different $\mathrm{pH}$ treatments $(P<0.001)$ (Fig. 5). After $60 \mathrm{~d}$ of irrigation water $\mathrm{pH}$ treatment, the chlorophyll content decreased by $0.8 \%, 16.2 \%$, and $40.4 \%$ at $\mathrm{pH}$ levels $5.8,7.0$, and 8.0 , respectively.

Mineral nUtRient analysis. Results of the soil nutrient analysis showed that $\mathrm{S}$ was the only nutrient in the soil unaffected by any of the treatments ( $\mathrm{pH}$ or disease). Irrigation water $\mathrm{pH}$ had a significant effect on the concentrations of $\mathrm{K}$, $\mathrm{Mg}, \mathrm{B}, \mathrm{Mn}, \mathrm{Fe}$, and $\mathrm{Cu}$ in the soil (Table 1). The $\mathrm{pH} 8.0$ treatment resulted in the least amount of $\mathrm{K}$ and $\mathrm{Fe}$ in the soil at the end of the experiment as compared with the $\mathrm{pH} 5.8$ and 7.0 treatments. Regardless of disease, soil from the $\mathrm{pH} 8.0$ treatment had the highest accumulations of $\mathrm{Mg}, \mathrm{B}, \mathrm{Mn}$, and $\mathrm{Cu}$, and soil from the $\mathrm{pH} 5.8$ treatment had the lowest concentrations. For soil $\mathrm{P}, \mathrm{Ca}$, and $\mathrm{Zn}$, there was a significant interaction

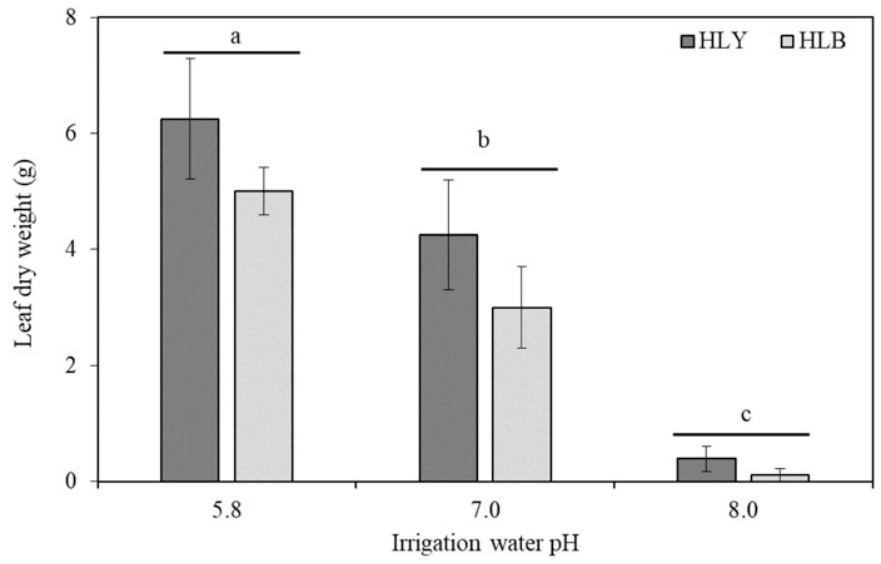

Fig. 4. Biomass of leaves (mean $\pm \mathrm{SE}$ ) of the healthy (HLY) and Huanglongbingaffected (HLB) sweet orange trees treated with irrigation water at $\mathrm{pH}$ levels of $5.8,7.0$, or 8.0 for $60 \mathrm{~d}(\mathrm{n}=8)$. Different letters indicate significant differences in the biomass of leaves of the trees treated with different $\mathrm{pH}$ levels regardless of the disease incidence using Tukey's honestly significant difference test at $P<0.05$.

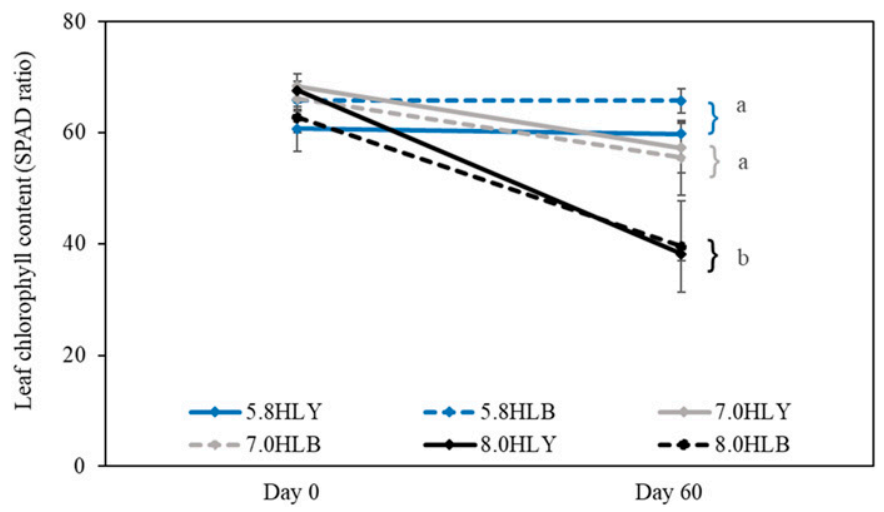

Fig. 5. Soil plant analysis development (SPAD) values (mean $\pm \mathrm{SE}$ ) for healthy (HLY) and Huanglongbing-affected (HLB) sweet orange trees at days 0 and 60 after being treated with irrigation water at $\mathrm{pH}$ levels of $5.8,7.0$, or $8.0(\mathrm{n}=$ 8). Different letters at the end of line indicate significant differences in the SPAD values of trees treated with different $\mathrm{pH}$ levels regardless of the disease incidence using Tukey's honestly significant difference test at $P<0.05$.

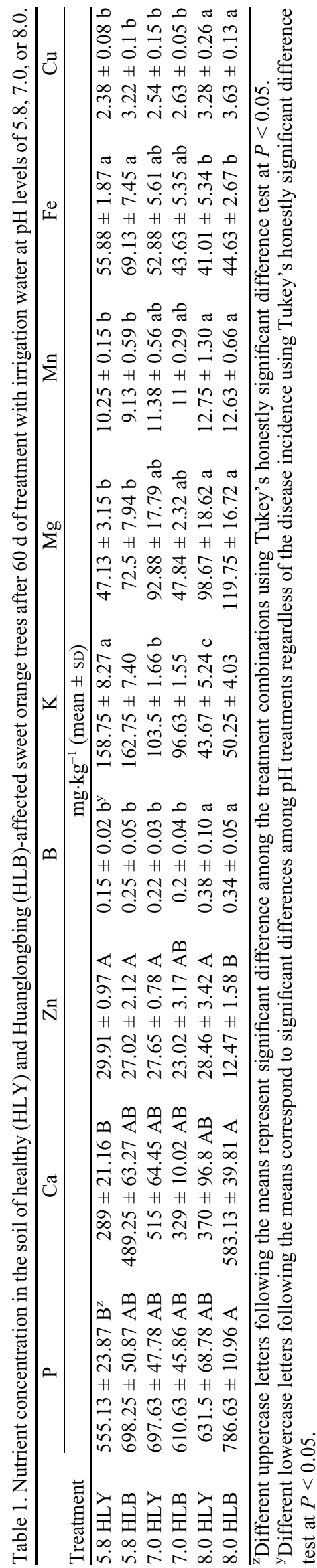

J. Amer. Soc. Hort. ScI. 145(5):318-327. 2020. 
$(\mathrm{pH} \times$ disease) $($ Table 1$)$. The $\mathrm{pH}$ had no influence on soil $\mathrm{P}$ and $\mathrm{Ca}$ of HLY trees; within a $\mathrm{pH}$ treatment, there were no differences in soil $\mathrm{P}$ and $\mathrm{Ca}$ of HLY and HLB trees. The $\mathrm{pH}$ also had no influence on soil Zn for HLY trees. In contrast, soil $\mathrm{Zn}$ from $\mathrm{pH}$ 5.8-HLB trees was greater than that from $\mathrm{pH} 8.0$ HLB trees. Soil Zn was only influenced by disease at the highest $\mathrm{pH}$.

The results of the leaf nutrient analysis are shown in Table 2. No statistical analysis could be performed because the leaves of all the replicates that underwent $\mathrm{pH} 8.0$ and 7.0 treatments (both HLY and HLB) had to be pooled to have sufficient tissue for analyses. All treatments showed an excess of P and K (Obreza and Morgan, 2008); phosphate buffers used in this study possibly contributed to such results. The $\mathrm{pH}$ 8.0-HLB trees were found to be deficient in $\mathrm{Ca}, \mathrm{Mg}$, and $\mathrm{Zn}$, whereas the nutrient levels resulting from all the other treatments were in the optimum to low range (Obreza and Morgan, 2008).

Transcriptomic analysis. Results of the transcriptomic analysis (Fig. 6) revealed that 274 genes were upregulated but no genes were downregulated in $\mathrm{pH}$ 8.0-HLB trees compared with $\mathrm{pH}$ 8.0-HLY trees. On the contrary, 520 genes were upregulated and 694 genes were downregulated in $\mathrm{pH}$ 5.8-HLB trees compared with pH 5.8-HLY trees.

GO ENRICHMENT ANALYSIS. The significant GO terms and their enrichment scores are provided as bar graphs in Supplemental Figs. 5-7. Highly enriched GO terms within the $\mathrm{pH} 5.8$ comparison were categorized as group 1 (Supplemental Fig. 5) and group 2 (Supplemental Fig. 6) for upregulated and downregulated genes, respectively. For highly enriched GO terms within the $\mathrm{pH} 8.0$ comparison, upregulated and downregulated genes were categorized as group 3 (Supplemental Fig. 7) and group 4, respectively (group 4 did not have any GO terms). The bubble plot in Figs. 7-9 highlights the superclusters of the 50 most enriched GO categories for each of the groups; each color of the bubble represents one supercluster, and the size of the bubble corresponds to the enrichment score of the respective GO category. The superclusters of GO categories enriched in group 1 (Fig. 7) included stress response, cell death-related processes, ROS metabolism, immune system, and ion transport processes. Some specific enriched GO categories were lipoprotein biosynthetic and metabolism (GO:0042158, GO:0042157), response to oxidative stress (GO:0006979), hydrogen peroxide metabolic process (GO:0042743), ROS metabolic process (GO:0072593), oxidation-reduction process (GO:0055114), terpenoid and isoprenoid metabolic process (GO:0006721, GO:0006720), immune response
(GO:0006955), $\mathrm{K}^{+}$transport (GO:0006813), carbohydrate transport (GO:0008643), ion transmembrane and transport (GO:0034220, GO:0006811), hormone metabolic process and regulation (GO:0042445; GO:0010817), development (GO:0048638, GO:0048507, GO:0021700, GO:0010016, GO:0048509), and root system development (GO:0022622).

In group 2, the most enriched GO superclusters were response to stress, host programmed cell death, hydrogen peroxide metabolism, and protein phosphorylation (Fig. 8). Some of the most enriched specific GO categories were oxylipin biosynthetic and metabolism (GO:0031408, GO:0031407), lipid oxidation and catabolism (GO:0034440, $\mathrm{GO}: 0030258$, GO:0044242), response to wounding (GO:0009611), defense response to bacterium (GO:0009816), immune system process and response (GO:0002376, GO:0006955), defense response (GO:0006952), and serine and glycine family metabolic process (GO:0009069, GO:0006544).

Within group 3, superclusters such as protein acylation, lignin metabolism, and immune system process and response to abiotic stimulus were observed (Fig. 9). The specific highly enriched GO categories included lignin metabolic process (GO:0009808), response to abscisic acid (ABA) (GO:0009737), secondary metabolic process (GO:0019748), response to stress (GO:0006950), regulation of defense response (GO:0031347), response to bacterium (GO:0009617), immune system process and response (GO:0002376, GO:0006955), programmed cell death and cell death (GO:0012501, GO:0008219), cell division (GO:0051301), root development (GO:0048364; GO:0022622), and regulation of growth (GO:0040008).

GENe EXPRESSION ANALYSIS. A significant correlation was observed between the results of qPCR and RNA-seq $(P=$ $0.008)$. Pearson's correlation coefficient $(r)$ was calculated as 0.93 when a correlation analysis was performed between fragments per kilobase of exons per million reads (FPKM) from the RNA-seq data and $\log _{2}$ fold change from the qPCR gene expression analysis (Supplemental Fig. 8).

\section{Discussion}

Undesirable effects on the growth and survival of HLY and HLB trees subjected to high-pH irrigation water were observed. Similar growth-restricting effects of high-pH irrigation water or soil $\mathrm{pH}$ conditions have been observed in the growth and leaf chlorophyll content of other crops such as french bean

Table 2. Nutrient concentration in the leaves of healthy (HLY) and Huanglongbing (HLB)-affected sweet orange trees after $60 \mathrm{~d}$ of treatment with irrigation water at $\mathrm{pH}$ levels of 5.8, 7.0, or 8.0 with the recommended optimum concentration in leaves of healthy citrus in Florida as described by Obreza and Morgan (2008).

\begin{tabular}{|c|c|c|c|c|c|c|c|c|c|c|}
\hline \multirow[b]{2}{*}{ Treatment } & $\mathrm{N}$ & $\mathrm{P}$ & $\mathrm{K}$ & $\mathrm{Mg}$ & $\mathrm{Ca}$ & B & $\mathrm{Zn}$ & $\mathrm{Mn}$ & $\mathrm{Fe}$ & $\mathrm{Cu}$ \\
\hline & \multicolumn{10}{|c|}{$\left(\mathrm{mg} \cdot \mathrm{kg}^{-1}\right)$} \\
\hline $5.8 \mathrm{HLY}$ & 28,000 & 9,800 & 33,600 & 2,700 & 18,800 & 66.40 & 30.66 & 65.72 & 147.81 & 8.92 \\
\hline 5.8 HLB & 30,900 & 10,600 & 37,700 & 2,600 & 15,800 & 80.26 & 35.84 & 98.27 & 146.60 & 8.49 \\
\hline 7.0 HLB & 35,300 & 5,100 & 31,500 & 3,000 & 20,200 & 90.82 & 33.32 & 110.24 & 170.15 & 9.33 \\
\hline 8.0 HLY & 26,500 & 6,200 & 26,100 & 3,400 & 15,500 & 53.71 & 27.75 & 73.54 & 105.90 & 7.92 \\
\hline 8.0 HLB & 31,600 & 2,200 & 20,300 & 1,700 & 9,100 & 45.88 & 10.73 & 84.85 & 98.73 & 4.08 \\
\hline
\end{tabular}




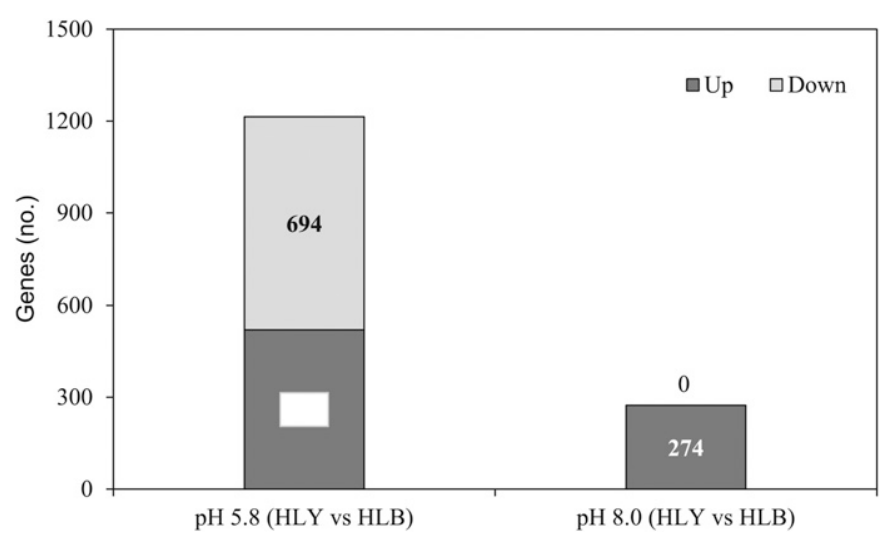

Fig. 6. Number of differentially expressed genes ( $\log _{2}$ fold change $>1$ and $P<$ 0.1 ) at day 60 in the feeder roots of Huanglongbing (HLB)-affected sweet orange trees compared with the healthy sweet orange trees after being treated with irrigation water at a $\mathrm{pH}$ level of 5.8 or 8.0 for $60 \mathrm{~d}$.

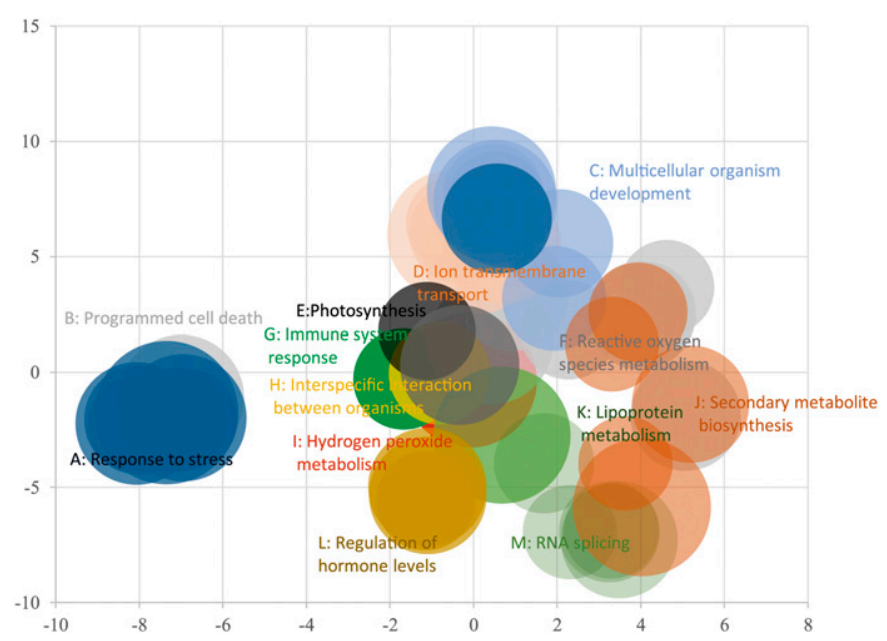

Fig. 7. Bubble plot with superclusters of the top 50 gene ontology (GO) terms of differentially upregulated genes (DEG) that were highly enriched in the roots of $\mathrm{pH}$ 5.8-treated Huanglongbing (HLB)-affected sweet orange trees compared with healthy sweet orange trees in the aspect of biological process. The size of the bubble corresponds to the enrichment score, and the color of the bubble represents individual superclusters.

(Phaseolus vulgaris), wheat (Triticum aestivum), maize [Zea mays (Islam et al., 1980)], blueberry [Vaccinium virgatum (Jiang et al., 2017)], grape [Vitis vinifera (Ksouri et al., 2007)], and rose [Rosa hybrida (Roosta and Rezaei, 2014)]. Healthy Florida citrus thrives in a soil $\mathrm{pH}$ range of 6.0 to 6.5 (Alva et al., 1999); therefore, a change beyond this optimum range is likely to increase tree stress. However, a strong significant correlation between irrigation water $\mathrm{pH}$ and increases in height, trunk diameter, leaf drop rate, and leaf dry weight among HLB trees and a nonsignificant or weak correlation for the same parameters among HLY trees suggest that the detrimental effects of high $\mathrm{pH}$ were more distinct in HLB-affected trees. Of all the treatments, $\mathrm{pH} 8.0-\mathrm{HLB}$ trees had the greatest leaf drop and mortality; however, the growth of HLY and HLB trees was comparable when irrigated with low-pH irrigation water.

The pH 5.8-HLY and HLB trees in this experiment had considerable new root growth as compared with trees subjected

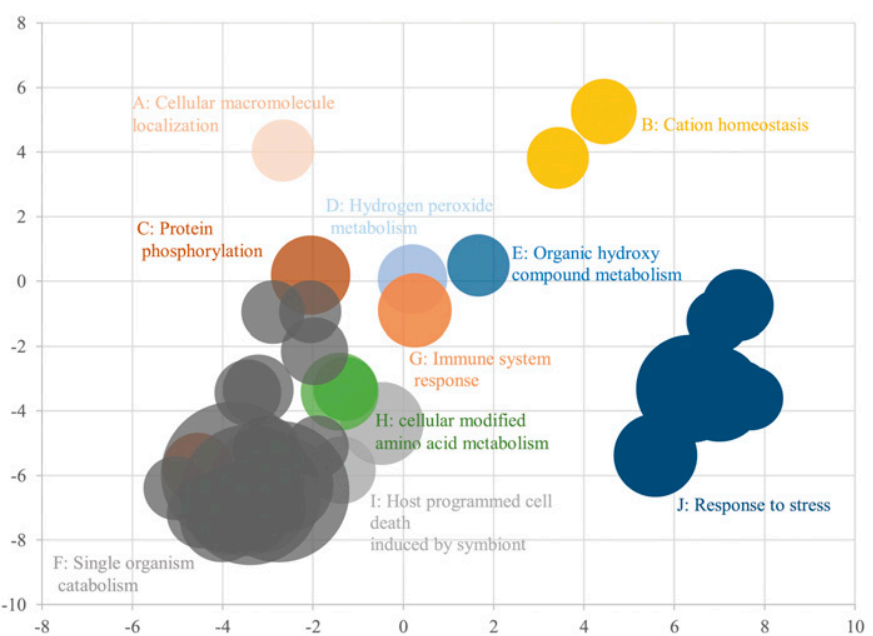

Fig. 8. Bubble plot with superclusters of the top 50 gene ontology (GO) terms of differentially downregulated genes (DEG) that were highly enriched in the roots of $\mathrm{pH}$ 5.8-treated Huanglongbing (HLB)-affected sweet orange trees compared with healthy sweet orange trees in the aspect of biological process. The size of the bubble corresponds to the enrichment score, and the color of bubble represents individual superclusters.

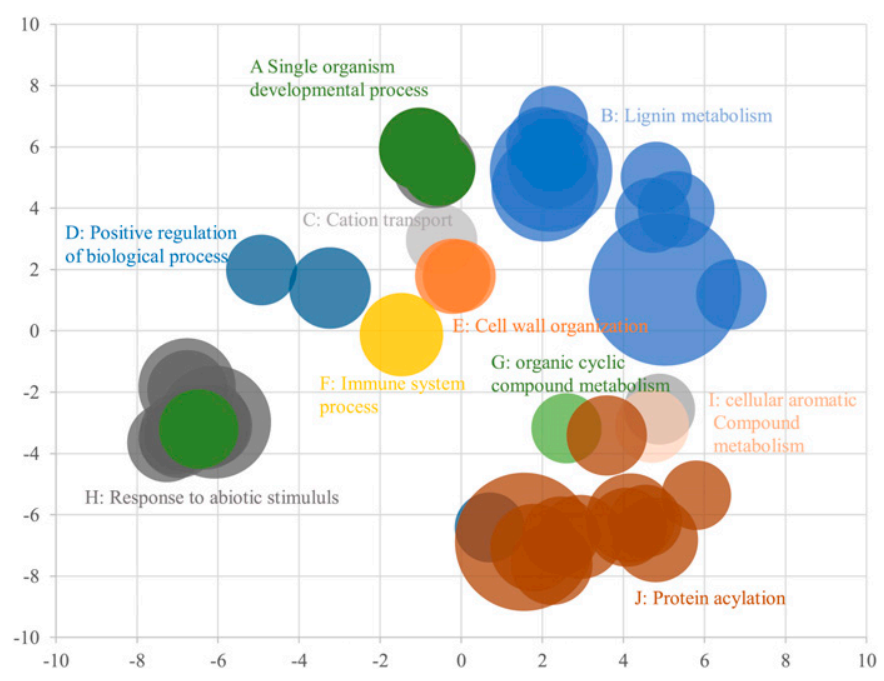

Fig. 9. Bubble plot with superclusters of the top 50 gene ontology (GO) terms of differentially upregulated genes (DEG) that were highly enriched in the roots of $\mathrm{pH}$ 8.0-treated Huanglongbing (HLB)-affected sweet orange trees compared with healthy sweet orange trees in the aspect of biological process. The size of the bubble corresponds to the enrichment score, and the color of the bubble represents individual superclusters.

to high-pH treatments, but the total root biomass did not reflect the root growth at low $\mathrm{pH}$ conditions because feeder roots are very thin and lightweight. When root biomass was measured, fine roots were not separated from structural roots; therefore, it is possible that the observed differences in feeder roots were not significant enough to affect the total root biomass. Nevertheless, fine roots can contribute significantly to the growth of the tree by facilitating nutrient uptake (Ding et al., 2019). This is further supported by the $\mathrm{pH} 8.0$-treated trees having higher EC values compared with treated with low $\mathrm{pH}$. This indicates the following possibilities: 1) an increase in EC was observed due to the poor uptake of minerals and nutrients by the trees, 2) the 
addition of the $\mathrm{pH} 8.0$ buffer increased the salt accumulation in the soil as compared with the low $\mathrm{pH}$ buffer; or both. When HLY and HLB trees were compared, the soil of HLB trees had a higher EC value, further suggesting that nutrient uptake by HLB trees was poor; this was possibly a consequence of HLBinduced root loss that reduces nutrient uptake (Johnson et al., 2014). This result is further supported by a deficiency of $\mathrm{Mg}$ (Obreza and Morgan, 2008) in the leaves of $\mathrm{pH}$ 8.0-HLB trees. Zinc is the most common nutrient deficiency reported in the leaves of HLB-affected trees (Masaoka et al., 2011). The low $\mathrm{Zn}$ content in the soil of $\mathrm{pH}$ 8.0-HLB and $\mathrm{pH}$ 7.0-HLB trees can be interpreted as high absorption of $\mathrm{Zn}$ by these trees, indicating that HLB-affected trees have a higher $\mathrm{Zn}$ demand leading to increased uptake. However, high absorption of $\mathrm{Zn}$ in $\mathrm{pH}$ 8.0-HLB trees along with $\mathrm{Zn}$ deficiency in the leaf tissues indicates either poor translocation of $\mathrm{Zn}$ from root to shoot or high $\mathrm{Zn}$ metabolism in physiological processes such as inhibition of apoptosis (Cakmak, 2000), possibly caused by high $\mathrm{pH}$ and HLB. In this study, such nutrient deficiency was not observed in $\mathrm{pH}$ 5.8-HLB trees or $\mathrm{pH}$ 8.0-HLY trees. Masaoka et al. (2011) and Morgan and Graham (2019) proposed that toxins produced from CLas-infected trees interact with Fe and $\mathrm{Zn}$ to reduce their availability to the tree.

The results of differences in the performance of HLBaffected and HLY trees at different $\mathrm{pH}$ levels and the effects of different $\mathrm{pH}$ levels on HLB-affected trees are further supported by the results of the transcriptomic analysis. The superclusters in group 1 (upregulated genes in pH 5.8-HLB vs $\mathrm{pH}$ 5.8-HLY) included stress response, cell death-related processes, ROS metabolism/detoxifying processes, immune system, ion transport processes, and developmental processes. The production of ROS increases under biotic and abiotic stress conditions, causing ROS to accumulate, which leads to oxidative stress that could damage cellular components such as DNA, lipids, proteins, and sugars (Pandhair and Sekhon, 2006). However, with the increase in the production of oxidative stress-induced ROS, trees tend to regulate several ROS scavenging pathways to detoxify the system. The transcriptomic analysis of alfalfa (Medicago sativa) revealed that the ROS scavenging pathway was dramatically upregulated under high$\mathrm{pH}$ stress (An et al., 2016). Trees upregulate antioxidant defenses to reduce the damaging effects of ROS (Apel and Hirt, 2004). Similarly, HLB-affected trees are known to accumulate ROS and undergo oxidative stress on infection and symptom development (Martinelli et al., 2013; Tang and Vashisth, 2020). Studies of HLB-affected trees have shown that key processes such as cell defense, transport, photosynthesis, carbohydrate metabolism, hormone biosynthesis, metabolism, and signal transduction are affected due to the disease (Albrecht and Bowman, 2008). CLas infection also leads to the inhibition of meristem development and initiation (Yu et al., 2017) and can cause up to $70 \%$ loss of fine root density (Johnson and Graham, 2015).

Altogether, the upregulation of oxidative stress-related genes in group 1 suggests the production of ROS in response to CLas infection in $\mathrm{pH}$ 5.8-HLB trees. However, several pathways involved in the ROS detoxification process upregulated simultaneously, reflecting the ability of $\mathrm{pH}$ 5.8-HLBaffected trees to minimize or neutralize the oxidative stress due to bacterial infection. Additionally, despite the presence of HLB, upregulation of genes related to several physiological and biochemical pathways involved in the developmental processes in group 1 supports that, in general, $\mathrm{pH}$ 5.8-HLB trees have more increased growth and developmental processes and metabolic activities than $\mathrm{pH}$ 5.8-HLY trees, suggesting there was reduced growth inhibition in roots and shoots as a result of HLB at low $\mathrm{pH}$. These results are in agreement with the visual observations made at low $\mathrm{pH}$, where the growth of HLB trees was better when compared with HLY trees.

In group 2 (downregulated genes in $\mathrm{pH}$ 5.8-HLB compared with $\mathrm{pH}$ 5.8-HLY), a significant number of genes was involved in pathways related to oxylipin biosynthesis and metabolism, lipid oxidation and catabolism, defense response to wounding and bacterium, immune response, and serine and glycine metabolism. ROS, which accumulate under abiotic and biotic stress conditions, can readily oxidize polyunsaturated fatty acids (PUFA) and lipid components, triggering lipid peroxidation due to the formation of lipid radicals that compromises membrane fluidity and integrity (Alché, 2019); therefore, lipid peroxidation is considered a positive indicator of stress. Various chemical changes in the damaged tissue occur in response to wounding from biotic or abiotic stress factors; this includes synthesis, metabolism or release of amino acids such as serine and glycine (Ashraf and Foolad, 2007), phenolic compounds such as alkaloids and flavonoids, and cell wall modifications and activation of metabolic pathways. Congruently, oxylipins (jasmonic acid) have been reported to have a pivotal role in the defense against plant pathogens through signaling pathways or protective compounds such as antibacterial or wound healing agents (Blée, 2002). Pathogen-infected plants usually exhibit enhanced levels of jasmonic acid (Alché, 2019). Increased jasmonic acid accumulation has been observed in HLB-affected sweet orange (Martinelli et al., 2013; Nehela et al., 2018).

The downregulation of genes related to jasmonic acid in HLB-affected trees in this study suggests a possible reduction in CLas infection. Overall, when comparing HLB and HLY pH 5.8 trees, the downregulation of genes involved in physiological and biochemical processes in response to stress hints at the growing conditions of $\mathrm{pH} 5.8$ being more favorable toward HLB trees than HLY trees.

Within group 3 (upregulated genes at $\mathrm{pH}$ 8.0-HLB compared to $\mathrm{pH}$ 8.0-HLY), there were numerous enriched GO categories related to stress, plant defense, ABA, cell death, apoptosis, and lignin metabolism. Lignin is one of the main components of the cell wall, and lignin metabolism has been related to the response of various environmental stresses and disease resistance in plants (Liu et al., 2018). Increased accumulation of lignin serves as a basic barrier against pathogen spread and reduces the infiltration of pathogen-released toxins and enzymes into the cell walls of plants (Santiago et al., 2013). In addition, lignin biosynthesis has been reported as crucial for hyperaccumulation of $\mathrm{Zn}$ and has a strong role in ion absorption and transportation in the roots (Van De Mortel et al., 2008). However, ABA and secondary metabolite production are well known to be related to stress mitigation strategies in plants. ABA accumulation has been reported in HLB-affected trees (Nehela et al., 2018). A study by Hu et al. (2017) reported that HLB-tolerant cultivars have a relative upregulation of secondary metabolic processes compared with susceptible cultivars, potentially contributing to CLas tolerance.

Overall, the upregulation of genes involved in response to stress, degradation, defense, ABA, secondary metabolites, and developmental processes and consequential cell death in roots 
is possibly induced by cumulative stress from high $\mathrm{pH}$ and HLB. This is supported by the observation of significant feeder root loss in $\mathrm{pH}$ 8.0-HLB trees. In addition, in $\mathrm{pH}$ 8.0-HLB trees, the number of genes involved in lignin biosynthesis, plant defense, and plant defense encoding proteins were observed, suggesting potential efforts to mitigate the effect of HLB/CLas infection. These results indicate that the physiological and metabolic processes of HLB trees were exacerbated under high $\mathrm{pH}$ conditions. It should be noted that all GO categories enriched in group 3 were not found to be significant in group 1 . The two GO terms, immune system process (GO:0002376) and immune response (GO:0006955), were downregulated in $\mathrm{pH}$ 5.8-HLB trees compared with $\mathrm{pH}$ 5.8-HLY trees were found to be upregulated in $\mathrm{pH}$ 8.0-HLB compared with $\mathrm{pH}$ 8.0-HLY trees. Hence, it can be inferred that irrigation water $\mathrm{pH}$ and HLB interact significantly, which affects the trees accordingly.

\section{Conclusions}

It can be concluded that irrigating trees with $\mathrm{pH} 8.0$ water resulted in severe damage to trees under HLB-affected conditions, whereas HLB-affected and $\mathrm{pH}$ 5.8-HLY trees performed similarly, as supported by growth and survival data. The results of the correlation analysis also indicated that increased $\mathrm{pH}$ has a severe impact on HLB trees compared with HLY trees. Moreover, RNA-sequencing results suggest that HLB-affected trees irrigated with $\mathrm{pH} 5.8$ were under less stress, maintained better plant defense response processes, experienced minimal hormonal imbalance, and thrived at the molecular level as compared with HLY trees when grown under low $\mathrm{pH}$ conditions for $60 \mathrm{~d}$. There appears to be an interaction between irrigation water $\mathrm{pH}$ and $C$ Las infection when HLB symptoms proliferate at a higher $\mathrm{pH}$ and are suppressed at low $\mathrm{pH}$. Our observations indicate that poor performance of HLB trees at high $\mathrm{pH}$ is not solely due to nutrient unavailability or the root damage; however, high $\mathrm{pH}$ in the presence of HLB causes detrimental effects at the physiological and molecular levels in trees. Acidifying soil is recommended to mitigate the effects of HLB; however, this should be a continuous process to account for the rebound of soil $\mathrm{pH}$ back to its normal level. Further studies of the regulation of growth of CLas with the change in soil or rhizosphere $\mathrm{pH}$ seem necessary to understand the reason for the better performance of HLB-affected trees at low $\mathrm{pH}$.

\section{Literature Cited}

Albrecht, U. and K.D. Bowman. 2008. Gene expression in Citrus sinensis (L.) Osbeck following infection with the bacterial pathogen Candidatus Liberibacter asiaticus causing Huanglongbing in Florida. Plant Sci. 175:291-306.

Alché, J.D. 2019. A concise appraisal of lipid oxidation and lipoxidation in higher plants. Redox Biol. 23:101-136.

Alva, A.K., B. Huang, O. Prakash, and S. Paramasivam. 1999. Effects of copper rates and soil $\mathrm{pH}$ on growth and nutrient uptake by citrus seedlings. J. Plant Nutr. 22:1687-1699.

An, Y.M., L.L. Song, Y.R. Liu, Y.J. Shu, and C.H. Guo. 2016. De novo transcriptional analysis of alfalfa in response to saline-alkaline stress. Front. Plant Sci. 7:1-14.

Apel, K. and H. Hirt. 2004. Reactive oxygen species: Metabolism, oxidative stress, and signal transduction. Annu. Rev. Plant Biol. 55:373-399. Ashraf, M. and M.R. Foolad. 2007. Roles of glycine betaine and proline in improving plant abiotic stress resistance. Environ. Exp. Bot. 59:206-216.
Bassanezi, R.B., L.H. Montesino, M.C.G. Gasparoto, A.B. Filho, and L. Amorim. 2011. Yield loss caused by Huanglongbing in different sweet orange cultivars in São Paulo, Brazil. Eur. J. Plant Pathol. 130:577-586.

Blée, E. 2002. Impact of phyto-oxylipins in plant defense. Trends Plant Sci. 7:315-322.

Bove, J.M. 2006. Huanglongbing: A destructive newly-emerging, century-old disease of citrus. J. Plant Pathol. 1:7-37.

Cakmak, I. 2000. Tansley review no. 111: Possible roles of zinc in protecting plant cells from damage by reactive oxygen species. New Phytol. 146:185-205.

Ding, W., P.L. Clode, and H. Lambers. 2019. Is pH the key reason why some Lupinus species are sensitive to calcareous soil? Plant Soil 434:185-201.

Golldack, D., C. Li, H. Mohan, and N. Probst. 2014. Tolerance to drought and salt stress in plants: Unraveling the signaling networks. Front. Plant Sci. 5:1-10.

Graham, J., E. Johnson, and K. Morgan. 2014. What growers need to know about bicarbonates and root health. Citrus Ind. 95(1):6-9.

Graham, J.H., E.G. Johnson, T.R. Gottwald, and M.S. Irey. 2013. Presymptomatic fibrous root decline in citrus trees caused by Huanglongbing and potential interaction with Phytophthora spp. Plant Dis. 97:1195-1199.

Halbert, S.E., C. Niblett, K.L. Manjunath, R.F. Lee, and L.G. Brown. 2000. Establishment of two new vectors of citrus pathogens in Florida. Proc. Intl. Soc. Citric. IX Congr. 13:1016-1017.

Hanumantharao, B., R.M. Nair, and H. Nayyar. 2016. Salinity and high temperature tolerance in mungbean [Vigna radiata $(\mathrm{L}$.$) Wilczek]$ from a physiological perspective. Front. Plant Sci. 7:1-20.

Hellemans, J., G. Mortier, A. De Paepe, F. Speleman, and J. Vandesompele. 2007. qBase relative quantification framework and software for management and automcheated analysis of real-time quantitative PCR data. Genome Biol. 8:R19.

Hu, Y., X. Zhong, X. Liu, B. Lou, C. Zhou, and X. Wang. 2017. Comparative transcriptome analysis unveils the tolerance mechanisms of Citrus hystrix in response to Candidatus Liberibacter Asiaticus infection. PLoS One 12:e0189229.

Islam, A.K.M.S., D.G. Edwards, and C.J. Asher. 1980. pH optima for crop growth - Results of a flowing solution culture experiment with six species. Plant Soil 54:339-357.

Jagoueix, S., J.M. Bové, and M. Garnier. 1996. PCR detection of the two Candidatus Liberibacter species associated with greening disease of citrus. Mol. Cell. Probes 10:43-50.

Jiang, Y., Y. Li, Q. Zeng, J. Wei, and H. Yu. 2017. The effect of soil pH on plant growth, leaf chlorophyll fluorescence and mineral element content of two blueberries. Acta Hort. 1180:269-275.

Johnson, E.G. and J.H. Graham. 2015. Root health in the age of HLB. Citrus Ind. 96(8):14-18.

Johnson, E.G., J. Wu, D.B. Bright, and J.H. Graham. 2014. Association of Candidatus Liberibacter asiaticus root infection, but not phloem plugging with root loss on Huanglongbing-affected trees prior to appearance of foliar symptoms. Plant Pathol. 63:290-298.

Kadyampakeni, D.M., K.T. Morgan, A.W. Schumann, and P. NkediKizza. 2014. Effect of irrigation pattern and timing on root density of young citrus trees infected with Huanglongbing disease. HortTechnology 24:209-221.

Ksouri, R., A. Debez, H. Mahmoudi, Z. Ouerghi, M. Gharsalli, and M. Lachaâl. 2007. Genotypic variability within Tunisian grapevine varieties (Vitis vinifera L.) facing bicarbonate-induced iron deficiency. Plant Physiol. Biochem. 45:315-322.

Liu, Q., L. Luo, and L. Zheng. 2018. Lignins: Biosynthesis and biological functions in plants. Intl. J. Mol. Sci. 19:335.

Mafra, V., K.S. Kubo, M. Alves-Ferreira, M. Ribeiro-Alves, R.M. Stuart, L.P. Boava, C.M. Rodrigues, and M.A. Machado. 2012. Reference genes for accurate transcript normalization in citrus genotypes under different experimental conditions. PLoS One 7:e31263.

Martinelli, F., S.L. Uratsu, U. Albrecht, R.L. Reagan, M.L. Phu, M. Britton, V. Buffalo, J. Fass, E. Leicht, W. Zhao, D. Lin, R. D’Souza, C.E. Davis, 
K.D. Bowman, and A.M. Dandekar. 2012. Transcriptome profiling of citrus fruit response to Huanglongbing disease. PLoS One 7:e38039.

Martinelli, F., R.L. Reagan, S.L. Uratsu, M.L. Phu, U. Albrecht, W. Zhao, C.E. Davis, K.D. Bowman, and A.M. Dandekar. 2013. Gene regulatory networks elucidating Huanglongbing disease mechanisms. PLoS One 8:e74256.

Masaoka, Y., A. Pustika, S. Subandiyah, A. Okada, E. Hanundin, B. Purwanto, M. Okuda, Y. Okada, A. Saito, P. Holford, A. Beattie, and T. Iwanami. 2011. Lower concentrations of microelements in leaves of citrus infected with Candidatus Liberibacter asiaticus. Jpn. Agr. Res. Qrtly. 45:269-275.

Mehlich, A. 1953. Determination of $\mathrm{P}, \mathrm{Ca}, \mathrm{Mg}, \mathrm{K}, \mathrm{Na}$, and $\mathrm{NH}_{4}$. North Carolina Soil Test Div., North Carolina Dept. Agr., Raleigh.

Mohan, C. 2003. A guide for the preparation and use of buffers in biological systems. EMD Biosciences, Darmstadt, Germany.

Morgan, K.T. and J.H. Graham. 2019. Nutrient status and root density of Huanglongbing-affected trees: Consequences of irrigation water bicarbonate and soil $\mathrm{pH}$ mitigation with acidification. Agronomy 9:746.

Munns, R. and M. Gilliham. 2015. Salinity tolerance of crops - What is the cost? New Phytol. 208:668-673.

Mylavarapu, R., J. Bergeron, N. Wilkinson, and E. Hanlon. 2020. Soil $\mathrm{pH}$ and electric conductivity: A county extension soil laboratory manual. Univ. Florida, Inst. Food Agr. Sci. Ext. CIR1081. 3 July 2020. $<$ https://edis.ifas.ufl.edu/ss118>.

National Center for Biotechnology Information. 2018. A tool for finding specific primers. 1 July 2018. <https://www.ncbi.nlm.nih. gov/tools/primer-blast/index.cgi $>$.

Nehela, Y., F. Hijaz, A.A. Elzaawely, H.M. El-Zahaby, and N. Killiny. 2018. Citrus phytohormonal response to Candidatus Liberibacter asiaticus and its vector Diaphorina citri. Physiol. Mol. Plant Pathol. 102:24-35.

Obreza, T.A. and K.T. Morgan. 2008. Nutrition of Florida citrus trees. 2nd ed. Univ. Florida, Inst. Food Agr. Sci. Ext. SL253. 16 Aug. 2019. $<$ https://edis.ifas.ufl.edu/ss478>.

Pandhair, V. and B.S. Sekhon. 2006. Reactive oxygen species and antioxidants in plants: An overview. J. Plant Biochem. Biotechnol. 15:71-78.

Pfaffl, M.W. 2001. A new mathematical model for relative quantification in real-time RT-PCR. Nucleic Acids Res. 29:e45.

Rio, D.C. 2015. Denaturation and electrophoresis of RNA with formaldehyde. Cold Spring Harb. Protoc. 2015:219-222.

Roosta, H.R. and I. Rezaei. 2014. Effect of nutrient solution $\mathrm{pH}$ on the vegetative and reproductive growth and physiological characteristics of rose cv. 'Grand Gala' in hydroponic system. J. Plant Nutr. 37:21792194.
Santiago, R., J. Barros-Rios, and R.A. Malvar. 2013. Impact of cell wall composition on maize resistance to pests and diseases. Intl. J. Mol. Sci. 14:6960-6980.

Shabala, S. and A. Mackay. 2011. Ion transport in halophytes. Adv. Bot. Res. 57:151-199.

Supek, F., M. Bošnjak, N. Škunca, and T. Šmuc. 2011. Revigo summarizes and visualizes long lists of gene ontology terms. PLoS One 6:e21800.

Tang, L. and T. Vashisth. 2020. New insight in Huanglongbingassociated mature fruit drop in citrus and its link to oxidative stress. Scientia Hort. 265:109246.

Tian, T., Y. Liu, H. Yan, Q. You, X. Yi, Z. Du, W. Xu, and Z. Su. 2017. AgriGO v2.0: A GO analysis toolkit for the agricultural community, 2017 update. Nucleic Acids Res. 45:W122-W129.

Van De Mortel, J.E., H. Schat, P.D. Moerland, E.V.L. Van Themaat, S. Van Der Ent, H. Blankestijn, A. Ghandilyan, S. Tsiatsiani, and M.G.M. Aarts. 2008. Expression differences for genes involved in lignin, glutathione and sulphate metabolism in response to cadmium in Arabidopsis thaliana and the related $\mathrm{Zn} / \mathrm{Cd}$-hyperaccumulator Thlaspi caerulescens. Plant Cell Environ. 31:301-324.

Vashisth, T. and C. Vincent. 2018. Living with yellow dragon disease. Citrus Ind. 99(3):10-13.

Vashisth, T. and T. Livingston. 2019. Assessment of pruning and controlled-release fertilizer to rejuvenate Huanglongbing-affected sweet orange. HortTechnology 29:933-940.

Wu, G.A., S. Prochnik, J. Jenkins, J. Salse, U. Hellsten, F. Murat, X. Perrier, M. Ruiz, S. Scalabrin, J. Terol, M.A. Takita, K. Labadie, J. Poulain, A. Couloux, K. Jabbari, F. Cattonaro, C.D. Fabbro, S. Pinosio, A. Zuccolo, J. Chapman, J. Grimwood, F.R. Tadeo, L.H. Estornell, J.V. Muñoz-Sanz, V. Ibanez, A. Herrero-Ortega, P. Aleza, J. Perez-Perez, D. Ramon, D. Brunel, F. Luro, C. Chen, W.G. Farmerie, B. Desany, C. Kodira, M. Mohiuddin, T. Harkins, K. Fredrikson, P. Burns, A. Lomsadze, M. Borodovsky, G. Reforgiato, J. Freitas-Astua, F. Quetier, L. Navarro, M. Roose, P. Wincker, J. Schmutz, M. Morgante, M.A. Machado, M. Talon, O. Jaillon, P. Ollitrault, F. Gmitter, and D. Rokhsar. 2014. Sequencing of diverse mandarin, pummelo and orange genomes reveals complex history of admixture during citrus domestication. Nat. Biotechnol. 32:656-662.

Yu, Q., C. Chen, D. Du, M. Huang, J. Yao, F. Yu, R.H. Brlansky, and F.G. Gmitter. 2017. Reprogramming of a defense signaling pathway in rough lemon and sweet orange is a critical element of the early response to Candidatus Liberibacter asiaticus. Hort. Res. 4:1-15.

Zhu, F.Y., M.X. Chen, N.H. Ye, W.M. Qiao, B. Gao, W.K. Law, Y. Tian, D. Zhang, D. Zhang, T.Y. Liu, and Q.J. Hu. 2018. Comparative performance of the BGISEQ-500 and Illumina HiSeq4000 sequencing platforms for transcriptome analysis in plants. Plant Methods 14:69. 


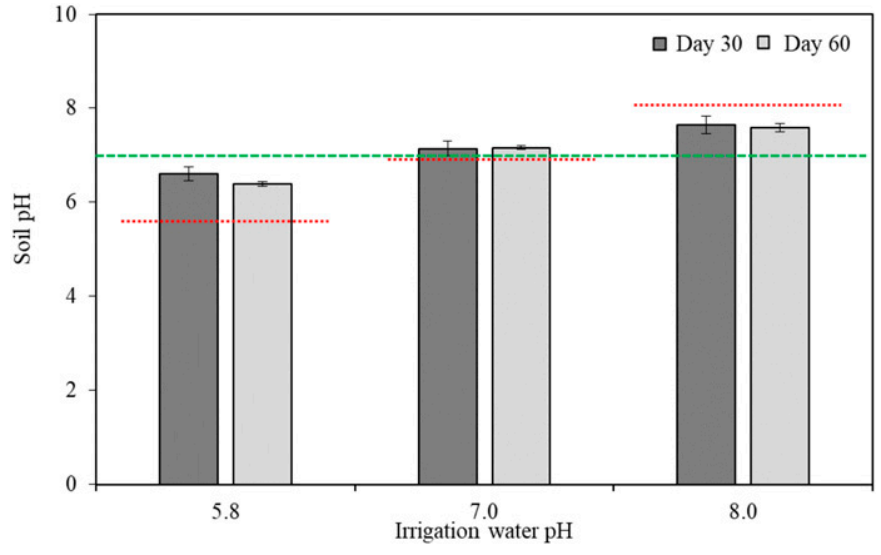

Supplemental Fig. 1. Average soil pH of healthy (HLY) and Huanglongbing (HLB)-affected sweet orange trees on days 30 and 60 after treatment with irrigation water at $\mathrm{pH}$ levels of 5.8, 7.0, or 8.0. Green line represents the original $\mathrm{pH}$ (7.2) of soil; red line represents the respective $\mathrm{pH}$ treatments.

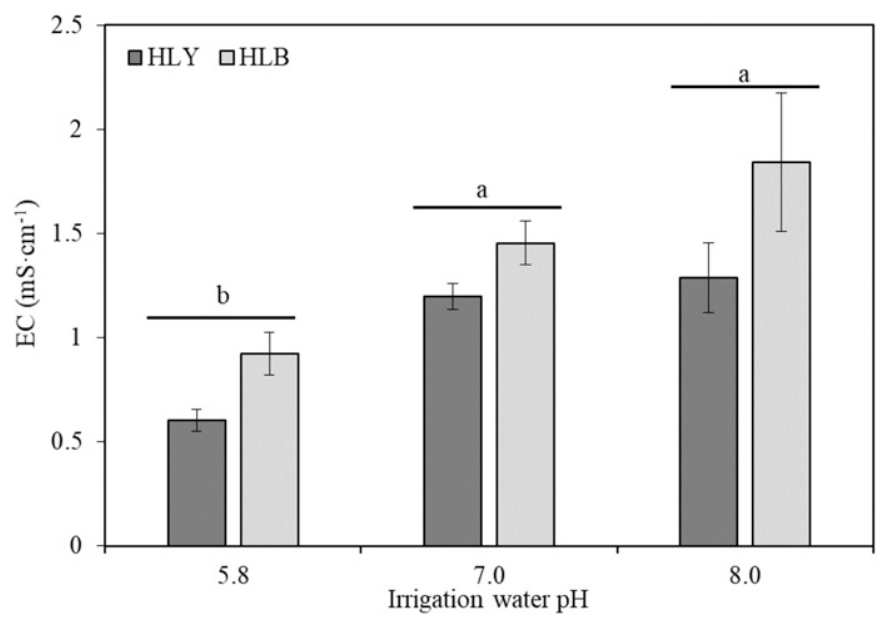

Supplemental Fig. 2. Electrical conductivity (EC) of the soil of healthy (HLY) and Huanglongbing (HLB)-affected sweet orange trees after $60 \mathrm{~d}$ of treatment with irrigation water at $\mathrm{pH}$ levels of 5.8,7.0, or 8.0. Data are mean $\pm \mathrm{SE}(\mathrm{n}=8)$. Different letters indicate significant differences among different $\mathrm{pH}$ regardless of the disease incidence using Tukey's honestly significant difference test at $P<0.05$.

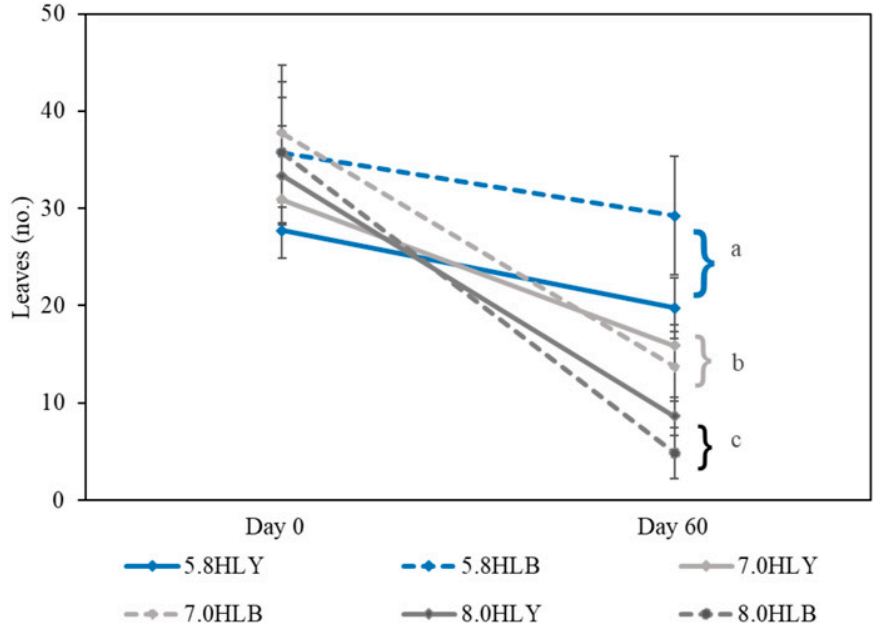

Supplemental Fig. 3. Leaf number of healthy (HLY) and Huanglongbing (HLB)-affected sweet orange trees treated with irrigation water at $\mathrm{pH}$ levels of $5.8,7.0$, or 8.0 at days 0 and 60 of the experiment. Data are means $\pm \operatorname{SE}(n=8)$. Different letters indicate significant differences in the leaf number of trees treated with different $\mathrm{pH}$ regardless of the disease incidence using Tukey's honestly significant difference test at $P<0.05$.

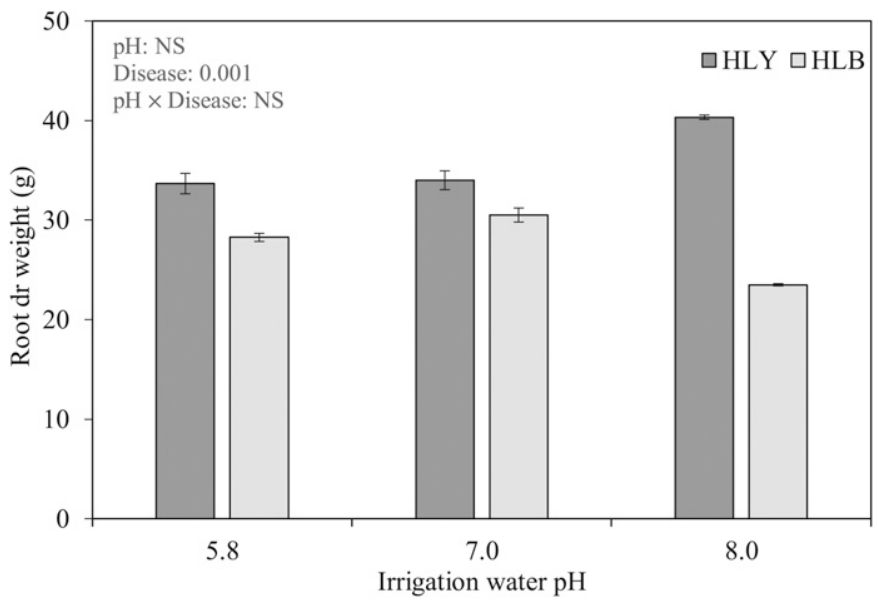

Supplemental Fig. 4. Dry root weight of the healthy (HLY) and Huanglongbing (HLB)-affected sweet orange trees after $60 \mathrm{~d}$ of treatment with irrigation water at $\mathrm{pH}$ levels of $5.8,7.0$, or 8.0. Data are means $\pm \mathrm{SE}(\mathrm{n}=8)$. 


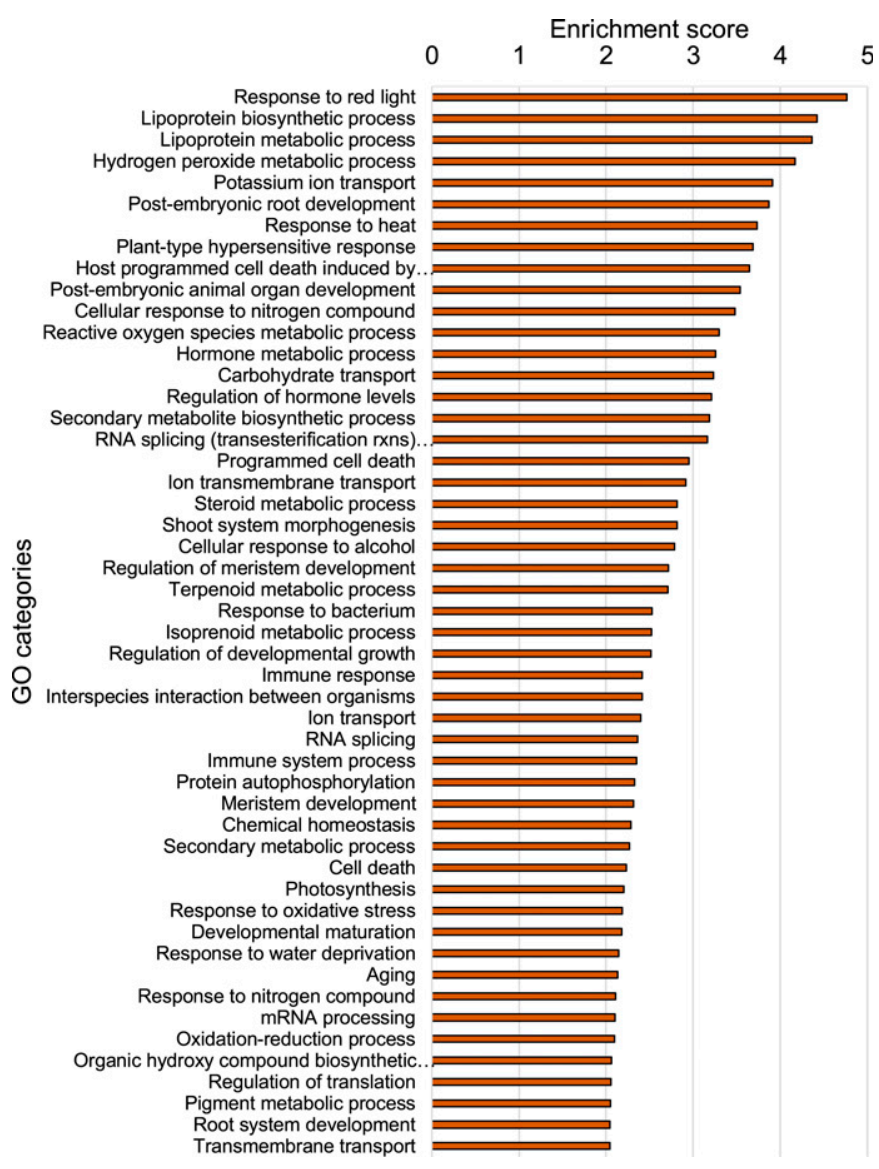

Supplemental Fig. 5. Top 50 Gene Ontology (GO) terms of differentially upregulated genes (DEG) based on enrichment scores in the roots of $\mathrm{pH} 5.8$ treated Huanglongbing-affected sweet orange trees compared with healthy sweet orange trees in the aspect of biological process.

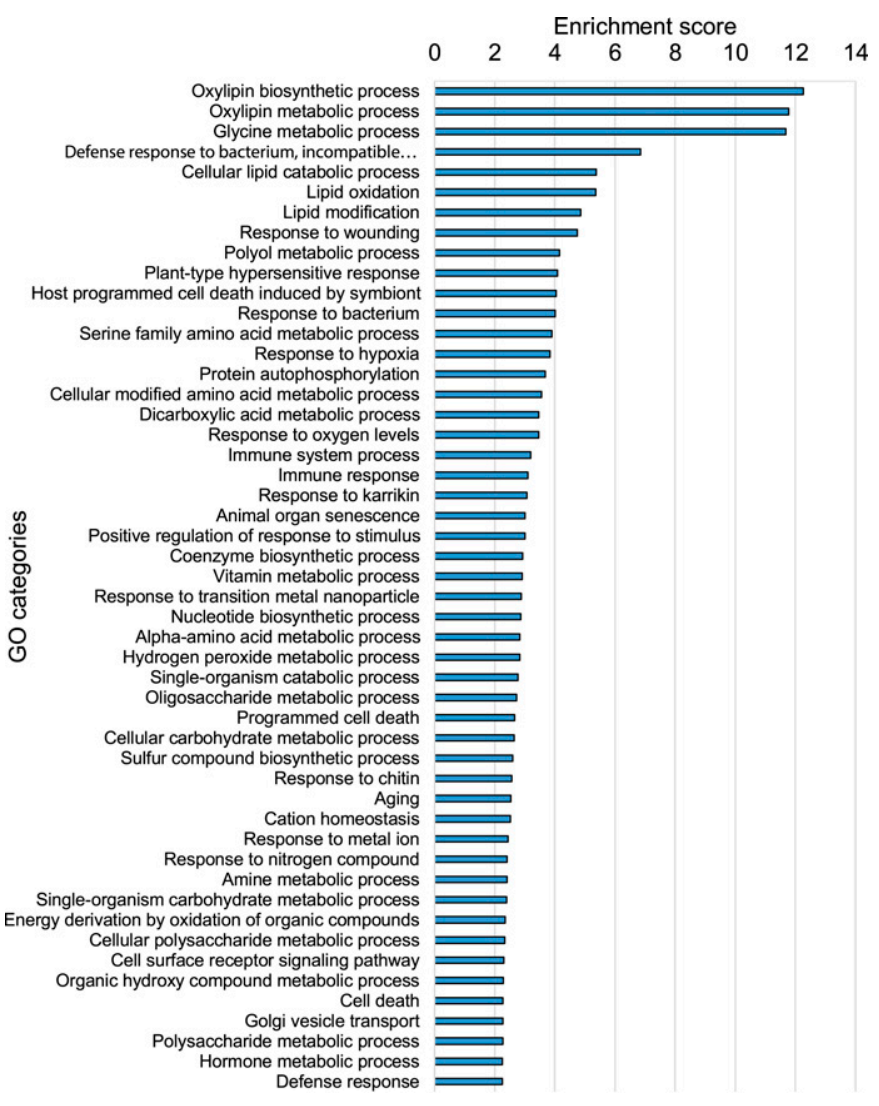

Supplemental Fig. 6. Top 50 Gene Ontology (GO) terms of differentially downregulated genes (DEG) based on enrichment scores in the roots of $\mathrm{pH}$ 5.8-treated Huanglongbing-affected sweet orange trees compared with healthy sweet orange trees in the aspect of biological process 


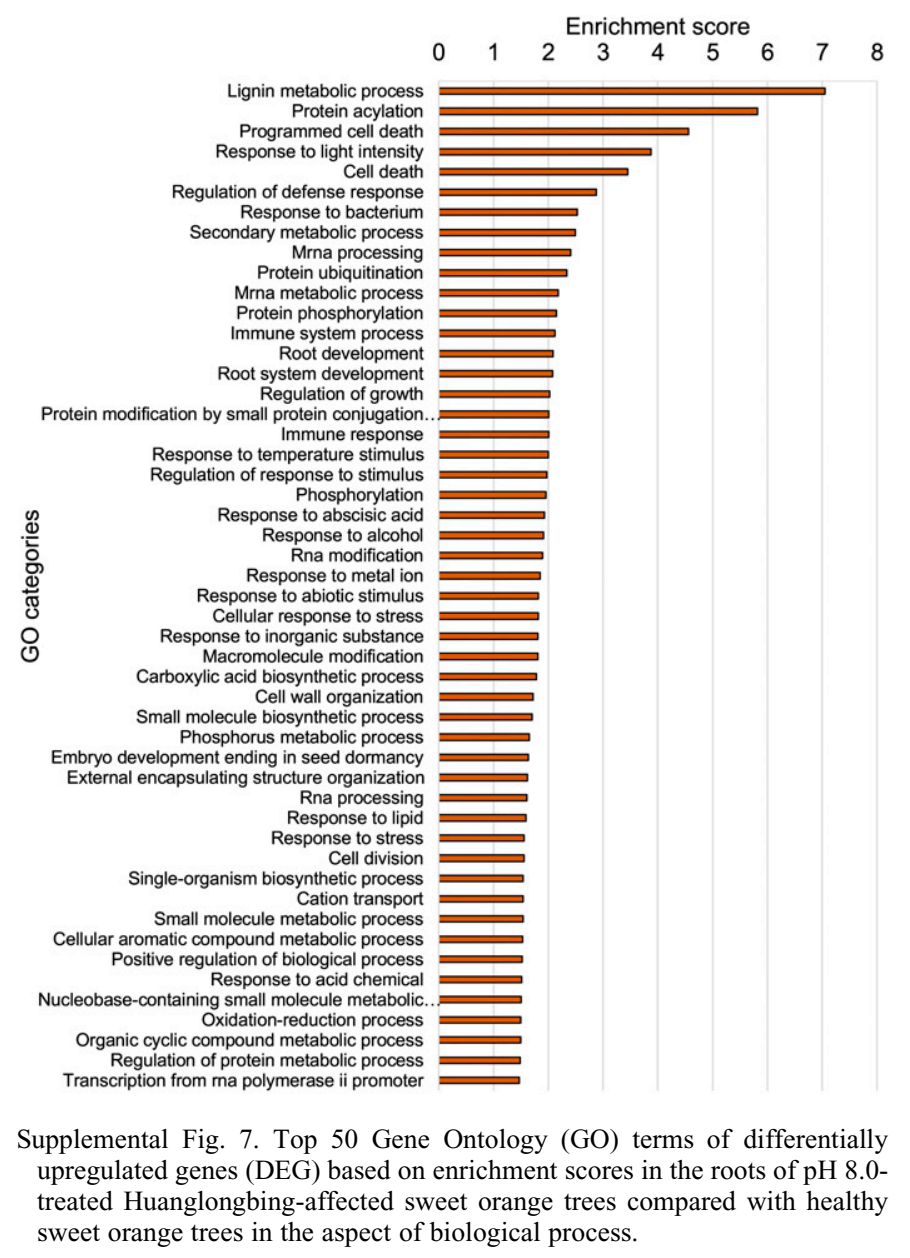

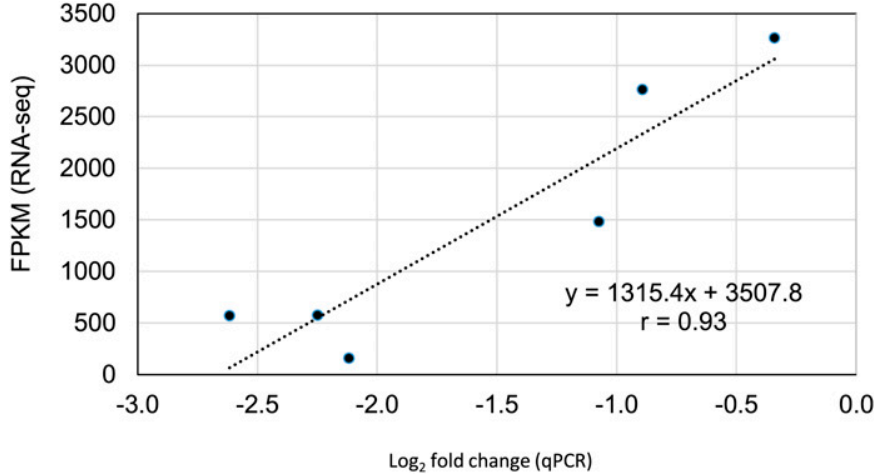

Supplemental Fig. 8. Relationship between relative expression $\left(\log _{2}\right.$ fold change) using quantitative real-time polymerase chain reaction (qPCR) and fragments per kilobase of exon per million reads (FPKM) derived from the RNA sequence of selected genes in the roots of Huanglongbing-affected and healthy sweet orange trees at $\mathrm{pH} 5.8$. 
Supplemental Table 1. List of genes and gene-specific primer sequences used for gene expression analysis in feeder roots of healthy and Huanglongbing-affected sweet orange plants treated with $\mathrm{pH} 5.8$ and 8.0 irrigation water for $60 \mathrm{~d}$.

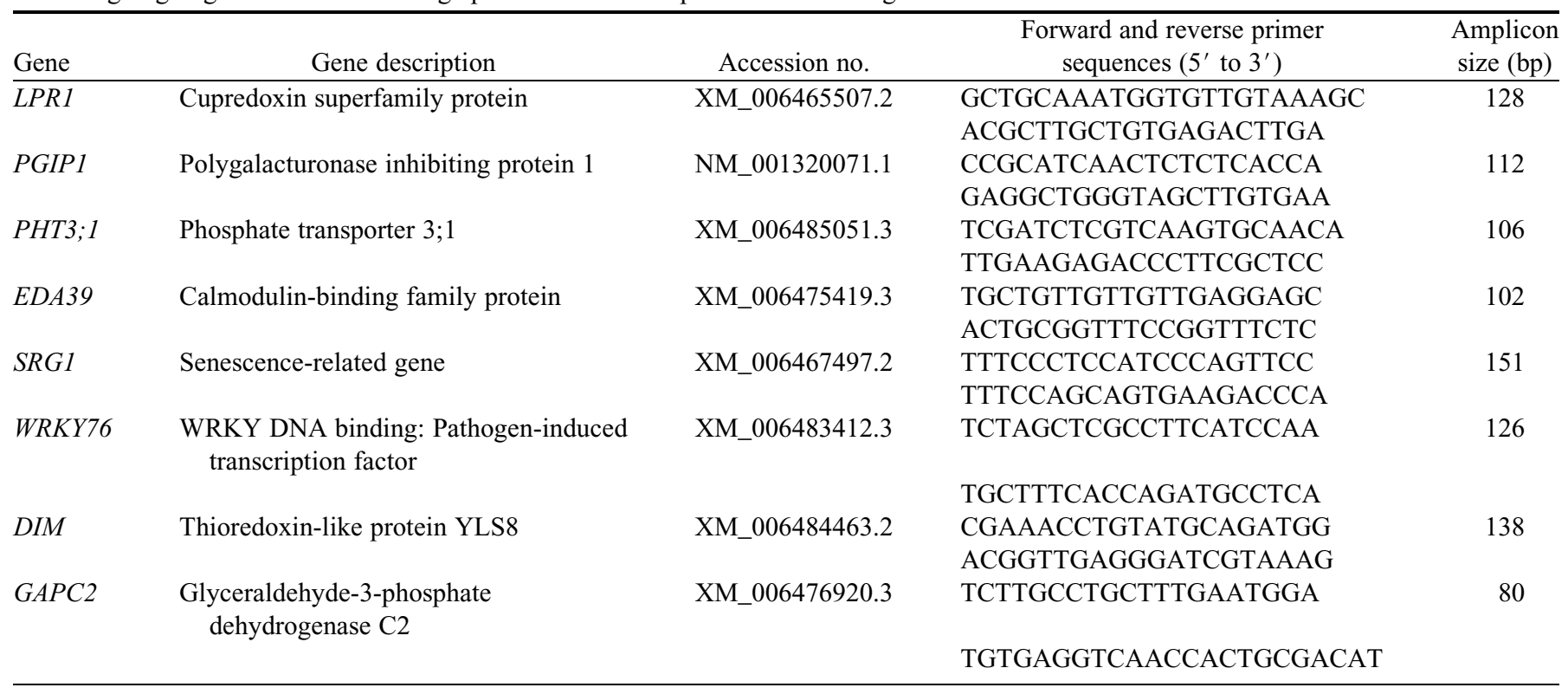

